\title{
First measurement of atmospheric mercury species in Qomolangma Natural Nature Preserve, Tibetan Plateau, and evidence of transboundary pollutant invasion
}

\author{
Huiming Lin ${ }^{1}$, Yindong Tong ${ }^{2}$, Xiufeng Yin ${ }^{3,4,5}$, Qianggong Zhang ${ }^{4,6}$, Hui Zhang ${ }^{7}$, Haoran Zhang ${ }^{1}$, Long Chen $^{8}$, \\ Shichang Kang ${ }^{3,5,6}$, Wei Zhang ${ }^{9}$, James Schauer ${ }^{10,11}$, Benjamin de Foy ${ }^{12}$, Xiaoge Bu ${ }^{2}$, and Xuejun Wang ${ }^{1}$ \\ ${ }^{1}$ MOE Laboratory of Earth Surface Processes, College of Urban and Environmental Sciences, \\ Peking University, Beijing, 100871, China \\ ${ }^{2}$ School of Environmental Science and Engineering, Tianjin University, Tianjin, 300072, China \\ ${ }^{3}$ State Key Laboratory of Cryospheric Science, Northwest Institute of Eco-Environment and Resources, \\ Chinese Academy of Sciences, Lanzhou, 730000, China \\ ${ }^{4}$ Key Laboratory of Tibetan Environment Changes and Land Surface Processes, Institute of Tibetan \\ Plateau Research, Chinese Academy of Sciences, Beijing, 100101, China \\ ${ }^{5}$ University of Chinese Academy of Sciences, Beijing, 100039, China \\ ${ }^{6}$ CAS Center for Excellence in Tibetan Plateau Earth Sciences, Beijing, 100085, China \\ ${ }^{7}$ State Key Laboratory of Environmental Geochemistry, Institute of Geochemistry, Chinese Academy of \\ Sciences, Guiyang, 550002, China \\ ${ }^{8}$ School of Geographic Sciences, East China Normal University, Shanghai, 200241, China \\ ${ }^{9}$ School of Environment and Natural Resources, Renmin University of China, Beijing, 100872, China \\ ${ }^{10}$ Department of Civil and Environmental Engineering, University of Wisconsin, Madison, WI 53706, USA \\ ${ }^{11}$ Wisconsin State Laboratory of Hygiene, University of Wisconsin, Madison, WI 53706, USA \\ ${ }^{12}$ Department of Earth and Atmospheric Sciences, Saint Louis University, Saint Louis, MO 63108, USA
}

Correspondence: Yindong Tong (yindongtong@tju.edu.cn) and Xuejun Wang (wangxuejun@pku.edu.cn)

Received: 5 August 2018 - Discussion started: 10 September 2018

Revised: 14 December 2018 - Accepted: 18 January 2019 - Published: 1 February 2019

\begin{abstract}
Located in the world's "third pole" and a remote region connecting the Indian plate and the Eurasian plate, Qomolangma National Nature Preserve (QNNP) is an ideal region to study the long-range transport of atmospheric pollutants. In this study, gaseous elemental mercury (GEM), gaseous oxidized mercury (GOM) and particle-bound mercury (PBM) were continuously measured during the Indian monsoon transition period in QNNP. A slight increase in the GEM concentration was observed from the period preceding the Indian summer monsoon $\left(1.31 \pm 0.42 \mathrm{ng} \mathrm{m}^{-3}\right)$ to the Indian summer monsoon period $\left(1.44 \pm 0.36 \mathrm{ng} \mathrm{m}^{-3}\right)$, while significant decreases were observed in the GOM and PBM concentrations, with concentrations decreasing from $35.2 \pm 18.6$ to $19.3 \pm 10.9 \mathrm{pg} \mathrm{m}^{-3}(p<0.001)$ for GOM and from $30.5 \pm 12.5$ to $24.9 \pm 19.8 \mathrm{pg} \mathrm{m}^{-3}(p<0.001)$ for PBM. A unique daily pattern was observed in QNNP with respect
\end{abstract}

to the GEM concentration, with a peak value before sunrise and a low value at noon. Relative to the (low) GEM concentrations, GOM concentrations (with a mean value of $21.4 \pm 13.4 \mathrm{pg} \mathrm{m}^{-3}, n=1239$ ) in this region were relatively high compared with the measured values in some other regions of China. A cluster analysis indicated that the air masses transported to QNNP changed significantly at different stages of the monsoon, and the major potential mercury $(\mathrm{Hg})$ sources shifted from northern India and western Nepal to eastern Nepal and Bangladesh. As there is a large area covered in glaciers in QNNP, local glacier winds could increase the transboundary transport of pollutants and transport polluted air masses to the Tibetan Plateau. The atmospheric $\mathrm{Hg}$ concentration in QNNP in the Indian summer monsoon period was influenced by transboundary $\mathrm{Hg}$ flows. This highlights the need for a more specific identification 
of Hg sources impacting QNNP and underscores the importance of international cooperation regarding global $\mathrm{Hg}$ controls.

\section{Introduction}

Understanding atmospheric mercury $(\mathrm{Hg})$ concentrations in remote regions is vital to comprehending global atmospheric $\mathrm{Hg}$ cycling processes (H. Zhang et al., 2016; Angot et al., 2016; AMAP/UNEP, 2013). Generally, atmospheric Hg can be divided into three major types: gaseous elemental $\mathrm{Hg}$ (GEM), gaseous oxidized $\mathrm{Hg}(\mathrm{GOM})$ and particle-bound $\mathrm{Hg}$ (PBM) (Selin, 2009). Over $95 \%$ of atmospheric $\mathrm{Hg}$ exists in the form of GEM (Ebinghaus et al., 2002; Huang et al., 2014). Due to its stable chemical properties and long atmospheric lifetime (approximately 0.3 to 1 year), GEM can be transported over long distances (Horowitz et al., 2017; Travnikov et al., 2017; Selin, 2009). In contrast, GOM and PBM can potentially deposit quickly from the atmosphere, exposing local environments to significant impacts (Lindberg and Stratton, 1998; Seigneur et al., 2006; Lynam et al., 2014). To understand the global and regional cycling of atmospheric $\mathrm{Hg}$, different $\mathrm{Hg}$ monitoring networks and sites have been established in recent decades, such as the Atmospheric Mercury Network (AMNet; Gay et al., 2013) and the Global Mercury Observation System (GMOS), which contains over 40 ground-based monitoring stations distributed throughout the world (Sprovieri et al., 2016). Generally, atmospheric $\mathrm{Hg}$ background concentrations range between 1.5 and 1.7 in the Northern Hemisphere and 1.1 and $1.3 \mathrm{ng} \mathrm{m}^{-3}$ in the Southern Hemisphere (Lindberg et al., 2007; Slemr et al., 2015; Venter et al., 2015; Sprovieri et al., 2016). However, existing studies are still far from sufficient with respect to obtaining a full understanding of long-range $\mathrm{Hg}$ transport because of insufficient monitoring data in remote and less populated regions (H. Zhang et al., 2015; Fu et al., 2012a).

The transboundary and long-range transport of pollutants have attracted considerable attention in the northeastern and southeastern regions of the Tibetan Plateau (Yang et al., 2018; Li et al., 2016; R. Zhang et al., 2015; Pokhrel et al., 2016). The transboundary flows of atmospheric pollutants to the Tibetan Plateau have been identified for contaminators such as persistent organic pollutants and black carbon (Yang et al., 2018; Li et al., 2016; R. Zhang et al., 2015; Pokhrel et al., 2016). It has also been reported that smoke from biomass burning on the Indian subcontinent could pass over the natural barrier of the Himalayas (Wang et al., 2015; Pokhrel et al., 2016). hexachlorocyclohexanes (HCHs), dichlorodiphenyltrichloroethanes (DDTs) and polychlorinated biphenyls (PCBs) were all found to have their highest concentrations on the southeastern Tibetan Plateau during the monsoon season (Wang et al., 2018). Similar conditions have also been reported for black carbon ( $\mathrm{Li}$ et al.,
2016). However, studies of the transboundary transport of $\mathrm{Hg}$ on the Tibetan Plateau are still limited. The existing Hg monitoring data are affected to varying extents by local emission sources (Fu et al., 2012a; H. Zhang et al., 2015, 2016). Fu et al. (2012a) reported that air masses with high $\mathrm{Hg}$ concentrations passed over the urban and industrial areas in western China and northern India, and influenced the atmospheric $\mathrm{Hg}$ concentrations in Waliguan on the northeastern edge of the Tibetan Plateau. At Shangri-La, located on the southeastern edge of the Tibetan Plateau, the atmospheric $\mathrm{Hg}$ sources were reported to be Southeast Asia, India and mainland China (H. Zhang et al., 2015). Nevertheless, studies are still lacking regarding transboundary transport of $\mathrm{Hg}$ in the Qomolangma National Nature Preserve (QNNP), which directly connects the Indian subcontinent and Eurasia. Therefore, the detailed pollutant transport pathways and seasonal or daily patterns of atmospheric $\mathrm{Hg}$ concentrations in this region are still not clear.

The QNNP, located on the southern edge of the Tibetan Plateau, is considered to be one of the world's cleanest regions (Qiu, 2008). With an average altitude of $\sim$ $4500 \mathrm{~m}$ a.s.l., the QNNP is a remote region with a sparse human population and rare industry (Qiu, 2008; Yao et al., 2012; Li et al., 2016). However, the preserve is surrounded by two large potential pollution sources: the populated and developed eastern China region, which has experienced about 30 years of rapid industrial development, and developing countries in South Asia (e.g., India, Nepal and Bangladesh), which have also been rapidly advancing in recent years (Streets et al., 2011; R. Zhang et al., 2015; Yang et al., 2018). China and India are reported as the largest coal consumers in the world (BP Statistical Review of World Energy, 2018), and coal combustion is the largest source of atmospheric $\mathrm{Hg}$ emissions globally, accounting for $\sim 86 \%$ of $\mathrm{Hg}$ emissions (G. Chen et al., 2016). China is predicted to become the largest economy in the world in the next 20-50 years, and India is predicted to catch up with the "Euro area" before 2030 (Pacyna et al., 2016). These rapidly growing economies have led to swift increases in energy demands and the subsequent increase of domestic $\mathrm{Hg}$ emissions (Pacyna et al., 2016). With the implementation of control strategies, atmospheric $\mathrm{Hg}$ emissions are forecast to be about 242 tonnes in China in 2020 (Wu et al., 2018). However, atmospheric Hg emissions in India are expected to increase to about 540 tonnes $\mathrm{Hg}$ by 2020 (Burger Chakraborty et al., 2013). As the QNNP is located on the pathway of air mass transport due to the Indian summer monsoon (ISM) (Li et al., 2016), meteorological conditions in the preserve vary significantly during the monsoon transition period (Wang et al., 2001). The monthly average precipitation can range from less than $50 \mathrm{~mm}$ in the non-ISM period to $950 \mathrm{~mm}$ in the ISM period (Panthi et al., 2015). In addition to the monsoon, the glacial coverage in QNNP is approximately $2710 \mathrm{~km}^{2}$ (Nie et al., 2010). Therefore, glacier winds could have direct effects on the local pollutant transport, as downslope glacier winds can transport 
polluted air from the upper levels to the land surface (Cai et al., 2007). Thus, the atmosphere in QNNP is vulnerable to surrounding pollution sources ( $\mathrm{Li}$ et al., 2016; Xu et al., 2009).

To the best of our knowledge, the present work is the first study regarding $\mathrm{Hg}$ monitoring and source identification in the QNNP that covers both the period preceding the Indian summer monsoon (PISM) and the Indian summer monsoon (ISM) period. We performed continuous measurements of GEM, GOM and PBM concentrations for 2 weeks during the onset of the monsoon and for 3.5 months during the monsoon itself. To identify the detailed sources, we combined the real-time $\mathrm{Hg}$ monitoring data with a backward trajectory analysis, clustering analysis and potential source contribution function (PSCF) analysis. We further discuss the effects of local glacier winds, caused by the large spatial extent of QNNP glaciers, on the transboundary transport of pollutants. This combined monitoring and modeling study could help researchers and governments to better understand global $\mathrm{Hg}$ cycling processes and the potential impacts from the rapidly developing countries in South Asia on the atmospheric $\mathrm{Hg}$ concentrations in QNNP.

\section{Materials and methods}

\subsection{Atmospheric Hg monitoring site}

Atmospheric $\mathrm{Hg}$ monitoring was conducted at the "Atmospheric and Environmental Comprehensive Observation and Research Station, Chinese Academy of Sciences" on Mt. Qomolangma $\left(28^{\circ} 21^{\prime} 54^{\prime \prime} \mathrm{N}, 86^{\circ} 56^{\prime} 53^{\prime \prime} \mathrm{E}\right)$ in the QNNP, at an altitude of $4276 \mathrm{~m}$ a.s.l. (Fig. 1). Mt. Qomolangma spreads from east to the west along the border between the Indian subcontinent and the Tibetan Plateau (Fig. 1). Due to its high altitude, the QNNP is naturally isolated from the populated regions, and only rare local $\mathrm{Hg}$ emission sources have been observed (AMAP/UNEP, 2013). The most populated region near the monitoring site is Tingri County (with a population density of 4 people per $\mathrm{km}^{2}$ ), which is located $\sim 40 \mathrm{~km}$ to the southwest. The average annual temperature in QNNP is $2.1^{\circ} \mathrm{C}$ and the total annual rainfall is $270.5 \mathrm{~mm}$ (P. Chen et al., 2016). QNNP is located along the air mass transport pathway of the ISM (Li et al., 2016), and the meteorological conditions in the region show significant variations between the PISM and ISM periods (Wang et al., 2001). During the transition period, the temperature on the Tibetan Plateau and in South Asia changes from "southern warm - northern cool" to "northern warm - southern cool" (Wang et al., 2001). This reversal leads to a significant increase of diabatic heating over South Asia and the southern slope of the Tibetan Plateau (Ge et al., 2018), which further affects the wind directions and speeds. Local glacier winds could also affect the transport of air masses in QNNP. Glaciers cover $\sim 2710 \mathrm{~km}^{2}$ in QNNP (Nie et al., 2010), and most of the

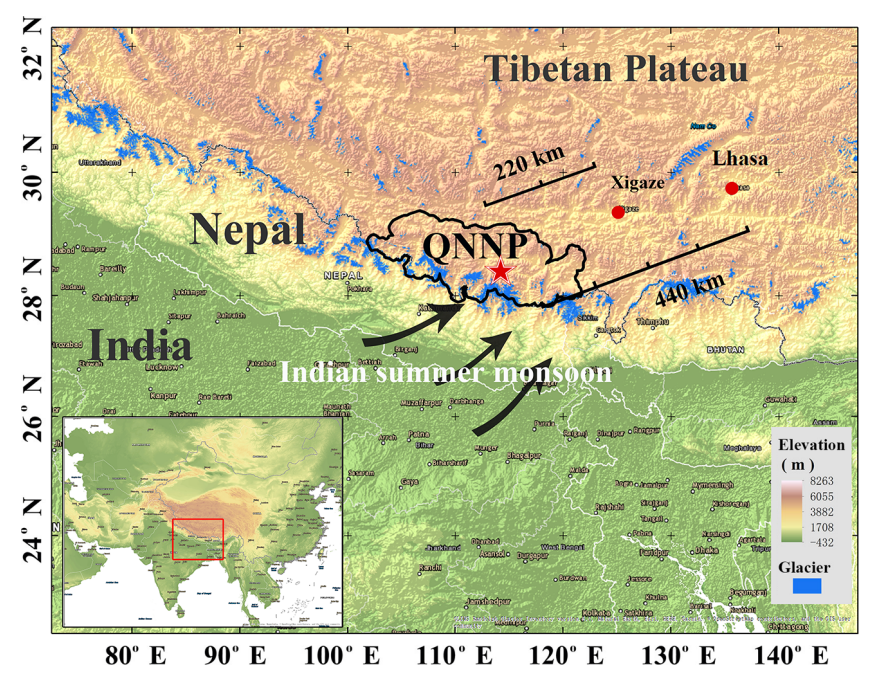

Figure 1. Location of Qomolangma National Nature Preserve (QNNP). The red star shows the location of the monitoring station in QNNP. The red dots show the locations of the two largest cities in Tibet (Lhasa and Xigaze), with the scale bars giving their distances from the QNNP.

glaciers are located on the northern slope of the mountain (Fig. 1; Bolch et al., 2012). The glacier wind is a continuous downslope wind that blows from glacier surfaces down to the foothills of the mountain throughout the day. Hence, the transport of air masses in this region is a combination of atmospheric circulation (monsoon) and local weather conditions (glacier winds). The structure of the boundary layer over QNNP is also significantly affected by glaciers (Li et al., 2006). The height of the atmospheric boundary layer follows a diurnal profile ranging from $\sim 350 \mathrm{~m}$ a.g.l. during the night to $\sim 2000 \mathrm{~m}$ a.g.l. during the day (Li et al., 2006).

\subsection{GEM, GOM and PBM monitoring}

To describe the changes in atmospheric $\mathrm{Hg}$ concentrations during the PISM and ISM periods, real-time continuous measurements of GEM, GOM and PBM concentrations were carried out using Tekran 2537B, 1130 and 1135 instruments (Tekran Inc., Toronto, Canada) from 15 April 2016 to $14 \mathrm{Au}-$ gust 2016. During the operation of the Tekran instruments, ambient air was introduced into the instrument for $60 \mathrm{~min}$ through an impactor, a KCl-coated annular denuder and a quartz fiber filter (QFF). All of the $\mathrm{Hg}$ species were converted to $\operatorname{Hg}(0)$ and then measured by cold vapor atomic fluorescence spectroscopy (CVAFS). The PBM and GOM collected were desorbed in succession to $\operatorname{Hg}(0)$ at the respective temperatures of 800 and $500^{\circ} \mathrm{C}$. $\mathrm{Hg}$-free air was used to flush the 1130 and 1135 systems to introduce the desorbed PBM and GOM into the model 2537B instrument for analysis. The GEM was collected at $5 \mathrm{~min}$ intervals. The sampling inlet was set at $\sim 1.5 \mathrm{~m}$ above the instrument platform (shown in Fig. S1 in the Supplement). To mitigate the 
impacts of low atmospheric pressures on the pump's train, low air sampling rates of $7 \mathrm{~L} \mathrm{~min}^{-1}$ for the pump model and $0.75 \mathrm{~L} \mathrm{~min}^{-1}$ (at a standard pressure of $1013 \mathrm{hPa}$ and temperature of $273.14 \mathrm{~K}$ ) for the model $2537 \mathrm{~B}$ instrument were applied (Swartzendruber et al., 2009; H. Zhang et al., 2015, 2016). The Tekran 2537B analyzer was calibrated automatically using the internal $\mathrm{Hg}$ permeation source inside the instrument every $23 \mathrm{~h}$, and the internal source was calibrated before and after monitoring by an external $\mathrm{Hg}$ source using a syringe. The Tekran ambient $\mathrm{Hg}$ analyzer has been described in more detail in previous publications (Landis et al., 2002; Rutter et al., 2008; de Foy et al., 2016). Recent studies have suggested that there may be a low bias of GOM and PBM concentrations for small sample loads of $\mathrm{Hg}$ (e.g., less than $10 \mathrm{pg}$ ) (Slemr et al., 2016; Ambrose, 2017). Hence, the monitoring data with GOM or PBM concentrations below $23.8 \mathrm{pg} \mathrm{m}^{-3}$ were recalculated using the method from Slemr et al. (2016). The updated concentrations increased slightly from $21.3 \pm 13.5$ to $21.4 \pm 13.4 \mathrm{pg} \mathrm{m}^{-3}$ for GOM and from $25.5 \pm 19.2$ to $25.6 \pm 19.1 \mathrm{pg} \mathrm{m}^{-3}$ for PBM.

\subsection{Meteorological data}

Throughout the sampling period, the meteorological information was recorded using a Vantage Pro2 weather station (Davis Instruments, USA) with a 5 min resolution. The parameters monitored included the temperature (with a precision of $0.1{ }^{\circ} \mathrm{C}$ ), the relative humidity (with a precision of $1 \%$ ), the wind speed (with a precision of $0.1 \mathrm{~m} \mathrm{~s}^{-1}$ ), the wind direction (with a precision of $1^{\circ}$ ), the air pressure (with a precision of $0.1 \mathrm{hPa}$ ), the solar radiation (with a precision of $1 \mathrm{~W} \mathrm{~m}^{-2}$ ) and the UV index (with a precision of 0.1 MEDs). The snow cover data were obtained from the Moderate Resolution Imaging Spectroradiometer (MODIS) instrument onboard the Terra and Aqua satellites (MOD10A1, Hall et al., 2010 ) with a daily $0.05^{\circ}$ resolution.

\subsection{Backward trajectory simulation}

To identify atmospheric $\mathrm{Hg}$ sources, the Hybrid SingleParticle Lagrangian Integrated Trajectory (HYSPLIT) model was applied to perform a backward trajectory simulation (Stein et al., 2015; Chai et al., 2016, 2017; Hurst and Davis, 2017). The HYSPLIT model, known as a complete and mature system for modeling air parcel trajectories of complex pollutant dispersion and deposition, was developed by the US National Oceanic and Atmospheric Administration (NOAA). Global Data Assimilation System (GDAS) data with $1^{\circ} \times 1^{\circ}$ latitude and longitude horizontal spatial resolution and 23 vertical levels at $6 \mathrm{~h}$ intervals were used for the backward trajectory simulation. All of the trajectory arrival heights were set to $1000 \mathrm{~m}$ a.g.l. Every backward trajectory was simulated for $72 \mathrm{~h}$ in $6 \mathrm{~h}$ intervals, and the air mass transport regions covered China, Nepal, India, Pakistan and the majority of western Asia. Backward trajectories during the whole monitoring period were calculated, and cluster analysis was carried out to identify the $\mathrm{Hg}$ transport pathways. The cluster statistics summarize the percentage of backward trajectories in each cluster, and the average GEM concentrations are linked with each cluster. The clustering algorithm utilized in this study is based on Ward's hierarchical method (Ward Jr., 1963), which minimizes angular distances between corresponding coordinates of the individual trajectories. By averaging similar or identical pathways from existing air mass pathways to the receptor site, clusters can help identify the mean transport pathways of air masses and provide the primary directions of pollutants transported to the measurement site.

The potential source contribution function (PSCF) model is a hybrid receptor model using the calculated backward trajectories to estimate the contributions of different emission sources in upwind regions and has been applied in many previous studies (Kaiser et al., 2007; Fu et al., 2012b; Kim et al., 2005; Zhang et al., 2013). The PSCF calculation is made based on counting the trajectory segments that terminate within each cell to determine the values for the grid cells in the study domain (Ashbaugh et al., 1985). In this study, the PSCF model was used to identify the possible sources of atmospheric GEM. The study domain was separated into $i \times j$ cells. Then, the PSCF value for the $i j$ th cell was defined as follows:

$\operatorname{PSCF}_{i j}=\frac{M_{i j}}{N_{i j}}$,

where $N_{i j}$ is the total number of endpoints that fall into the $i j$ th cell during the whole simulation period, and $M_{i j}$ is the number of endpoints for the same cell that correspond to GEM concentrations higher than a set criterion. In this study, PSCF values were calculated based on the average GEM concentration during the whole sampling campaign. The PSCF value stands for the conditional probability that the GEM concentration at the measurement site is larger than the average GEM concentration if the parcel passes through the $i j$ th cell before it reaches the measurement site.

To account for and reduce the uncertainty due to low values of $N_{i j}$, the PSCF values were scaled by an arbitrary weighting function $W_{i j}$ (Polissar et al., 1999). When the total number of the endpoints in a cell $\left(N_{i j}\right)$ is less than approximately three times the average value of the endpoints for each cell, the weighting function will decrease the PSCF values. In this study, $W_{i j}$ was set using the following piecewise function:

$W_{i j}=\left\{\begin{array}{l}1.00 N_{i j}>3 N_{\mathrm{ave}} \\ 0.703 N_{\mathrm{ave}}>N_{i j}>1.5 N_{\mathrm{ave}} \\ 0.421 .5 N_{\mathrm{ave}}>N_{i j}>N_{\mathrm{ave}} \\ 0.05 N_{\mathrm{ave}}>N_{i j}\end{array}\right.$

We used the PSCF analysis to evaluate the effects of biomass burning regions using the MODIS fire data. MODIS fire 
spots data from 1 April 2016 to 31 August 2016 were obtained from the Fire Information for Resource Management System (FIRMS) operated by the National Aeronautics and Space Administration (NASA) (Giglio et al., 2003; Davies et al., 2009).

\section{Results and discussion}

\subsection{Comparisons of atmospheric $\mathrm{Hg}$ concentrations between the PISM and ISM}

The GEM, GOM and PBM concentrations at the sampling site were $1.42 \pm 0.37 \mathrm{ng} \mathrm{m}^{-3}(n=15180), 21.4 \pm$ $13.4 \mathrm{pg} \mathrm{m}^{-3}(n=1239)$ and $25.6 \pm 19.1 \mathrm{pg} \mathrm{m}^{-3}(n=1237)$, respectively, during the whole study period (Fig. 2, Table 1). GEM accounted for over $95 \%$ of all the atmospheric $\mathrm{Hg}$ species. Figure S2 shows a comparison of the GEM, GOM and PBM concentrations during the PISM and ISM periods. During the PISM period, the average GEM, GOM and PBM concentrations were $1.31 \pm 0.42 \mathrm{ng} \mathrm{m}^{-3}(n=2001)$, $35.2 \pm 18.6 \mathrm{pg} \mathrm{m}^{-3}(n=167)$ and $30.5 \pm 12.5 \mathrm{pg} \mathrm{m}^{-3}(n=$ 168 ), respectively, while during the ISM period, the average GEM, GOM and PBM concentrations were $1.44 \pm$ $0.36 \mathrm{ng} \mathrm{m}^{-3} \quad(n=13179), 19.3 \pm 10.9 \mathrm{pg} \mathrm{m}^{-3} \quad(n=1072)$ and $24.9 \pm 19.8 \mathrm{pg} \mathrm{m}^{-3}$ ( $\left.n=1069\right)$, respectively. The concentrations of GEM, GOM and PBM are significantly different $(p<0.001)$ between the PISM and ISM periods. We further compared the Hg concentrations at different ISM stages. Figure S2 shows that GEM concentrations increased significantly with the development of the ISM ( $p<0.001$ between ISM1 and ISM4), while decreases in the GOM and PBM concentrations were observed during the study pe$\operatorname{riod}(p<0.001$ between ISM1 and ISM5), with decreases of $37.9 \%$ (from $20.3 \pm 7.38$ to $12.6 \pm 8.82 \mathrm{pg} \mathrm{m}^{-3}$ ) and $48.1 \%$ (from $21.2 \pm 7.38$ to $11.0 \pm 5.85 \mathrm{pg} \mathrm{m}^{-3}$ ), respectively. The reason for the higher PBM concentrations during ISM2 is discussed in Sect. 3.3.2.

Table 2 summarizes the GEM, GOM and PBM concentrations and the diurnal variations of GEM measured by the Tekran system in some previous studies in Asia. Generally, the GEM concentration in the QNNP was similar to the reported values in the Northern Hemisphere $(\sim 1.5$ to $1.7 \mathrm{ng} \mathrm{m}^{-3}$ ) and was higher than those found in the Southern Hemisphere ( $\sim 1.1$ to $1.3 \mathrm{ng} \mathrm{m}^{-3}$ ) (Lindberg et al., 2007; Slemr et al., 2015; Venter et al., 2015; Sprovieri et al., 2016). Among the global Hg monitoring sites, the Ev-K2CNR monitoring site on the southern slope of the Tibetan Plateau, Nepal, is the nearest station (at a straight-line distance of approximately $50 \mathrm{~km}$ ) from the monitoring site used in this study (Gratz et al., 2013). The average GEM concentration at Ev-K2-CNR $\left(1.2 \pm 0.2 \mathrm{ng} \mathrm{m}^{-3}\right.$, from November 2011 to April 2012) was slightly lower than that in the QNNP $\left(1.31 \pm 0.42 \mathrm{ng} \mathrm{m}^{-3}\right.$ during the PISM period and $1.44 \pm 0.36 \mathrm{ng} \mathrm{m}^{-3}$ during the ISM period). Compared with the Hg concentration at Nam Co Station (Yin et al., 2018) on the central Tibetan plateau $\left(1.33 \pm 0.24 \mathrm{ng} \mathrm{m}^{-3}\right)$, the GEM concentration in QNNP was higher during the ISM period. Compared with $\mathrm{Hg}$ concentrations observed at China's background stations and rural regions (e.g., Waliguan Baseline Observatory: $1.98 \pm 0.98 \mathrm{ng} \mathrm{m}^{-3}$; Fu et al., 2012a, Ailaoshan Mountain National Natural Reserve: $2.09 \pm 0.63 \mathrm{ng} \mathrm{m}^{-3}$; and Shangri-La Baseline Observatory in Yunnan Province: $2.55 \pm 0.73 \mathrm{ng} \mathrm{m}^{-3}, \mathrm{H}$. Zhang et al., 2016, 2015), the average GEM concentration in the QNNP was lower. Nevertheless, despite its low GEM concentration, the GOM concentration in QNNP was relatively high $\left(21.4 \pm 13.4 \mathrm{pg} \mathrm{m}^{-3}\right)$ compared with the values in the clean regions (usually lower than $10 \mathrm{pg} \mathrm{m}^{-3}$, Table 2) or even some polluted regions of China, such as the suburban areas of Beijing $\left(10.1 \pm 18.8 \mathrm{pg} \mathrm{m}^{-3}\right)$ and Shanghai $\left(21 \pm 100 \mathrm{pg} \mathrm{m}^{-3}\right.$ ) (Zhang et al., 2013; Duan et al., 2017; Table 2). One possible explanation for the high GOM concentration is the strong subsidence in the QNNP. The subsidence of the free troposphere would bring GOMenriched air masses to the surface layer (Faïn et al., 2009), resulting in the observed high surface GOM levels (WeissPenzias et al., 2009). In QNNP, due to the wide distribution of glaciers, glacier winds could bring the upper air masses to the land surface layer (Song et al., 2007), which could further strengthen the subsidence movement. The low wet deposition rate of GOM caused by the rare precipitation in the QNNP region $(\sim 270 \mathrm{~mm})$ (W.-K. Chen et al., 2016) could be another reason for the high GOM concentrations (Prestbo and Gay, 2009).

The increases of GEM concentrations during the ISM period could indicate the impacts of transboundary transport, which has been confirmed by previous studies (Fu et al., 2012a; H. Zhang et al., 2016). The deposition of GEM from the atmosphere to the land surface is difficult, and GEM has a much longer residence time than the other $\mathrm{Hg}$ species (Horowitz et al., 2017; Travnikov et al., 2017; Selin, 2009). At Ailaoshan in Yunnan Province (H. Zhang et al., 2016), a higher TGM concentration was observed during the ISM period $\left(2.22 \pm 0.58 \mathrm{ng} \mathrm{m}^{-3}\right)$ than during the PISM period $\left(1.99 \pm 0.66 \mathrm{ng} \mathrm{m}^{-3}\right)$. The TGM concentration during the ISM period $\left(2.00 \pm 0.77 \mathrm{ng} \mathrm{m}^{-3}\right)$ was also higher than that during the PISM period $\left(1.83 \pm 0.78 \mathrm{ng} \mathrm{m}^{-3}\right)$ at Waliguan Station in the northeastern Tibetan Plateau (Fu et al., 2012a). In contrast to GEM, the GOM and PBM levels during the ISM period were lower than the monitored values during the PISM period (Fig. S2, Table 2). In previous studies, the PBM concentration in the Kathmandu Valley was lower during the monsoon period $\left(120.5 \pm 105.9 \mathrm{pg} \mathrm{m}^{-3}\right)$ than during the pre-monsoon $\left(1855.4 \pm 780.8 \mathrm{pg} \mathrm{m}^{-3}\right)$ or the postmonsoon period $\left(237.6 \pm 199.4 \mathrm{pg} \mathrm{m}^{-3}\right)$ (Guo et al., 2017). In India, PBM concentrations during the monsoon period $\left(158 \pm 34 \mathrm{pg} \mathrm{m}^{-3}\right)$ were lower than those in the non-monsoon season $\left(231 \pm 51 \mathrm{pg} \mathrm{m}^{-3}\right)$ (Das et al., 2016). This fact could possibly be attributed to precipitation increases brought on by the monsoon, which cause further wet deposition of PBM 


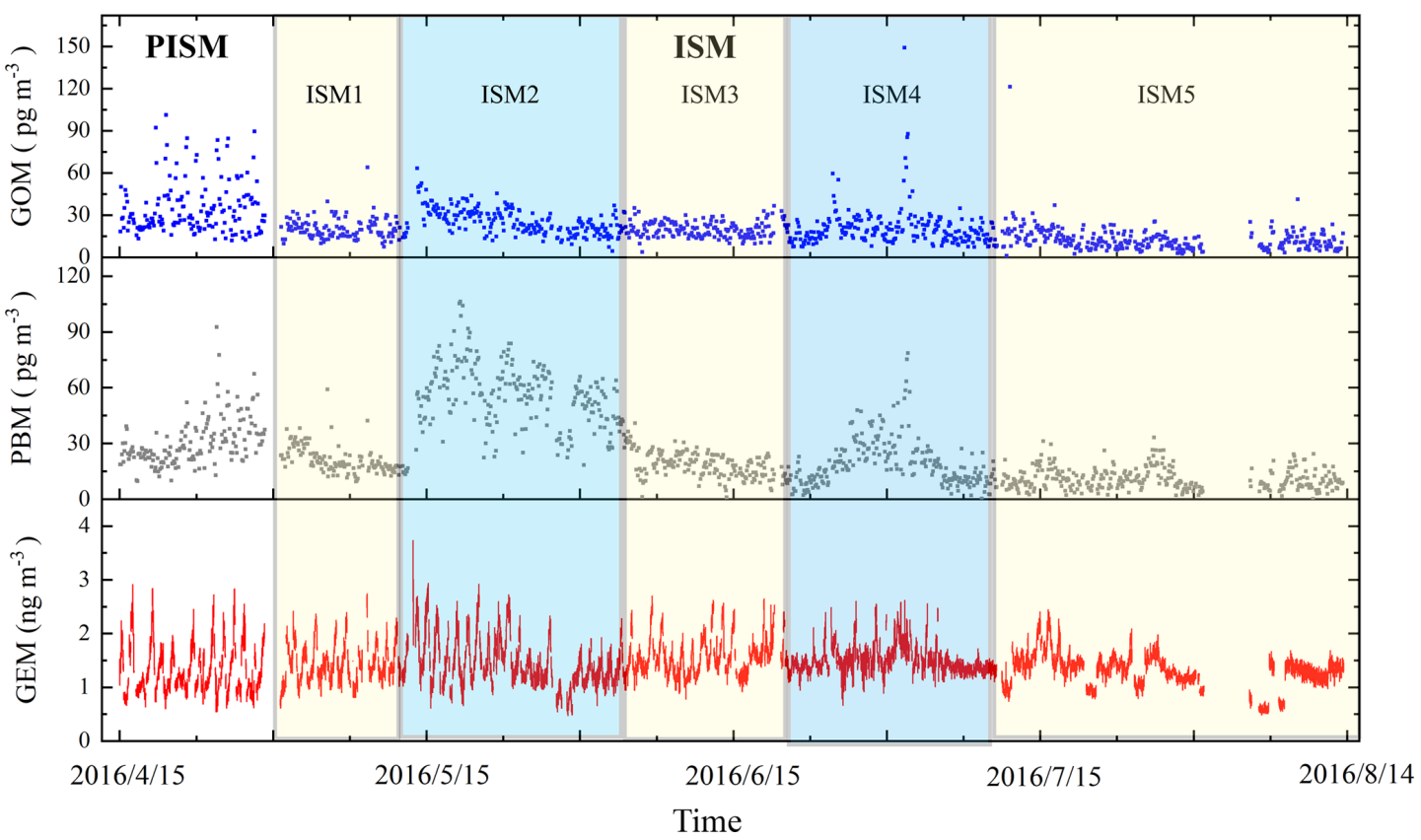

Figure 2. Time series change of GEM, GOM and PBM concentrations during the study period. The time series was split into a pre-Indian summer monsoon (PISM) period and five Indian summer monsoon (ISM) periods as follows: 15-30 April 2016 (PISM), 1-12 May (ISM1), 13 May-4 June (ISM2), 5-20 June (ISM3), 21 June-10 July (ISM4) and 11 July-14 August (ISM5).

from the atmosphere. During the ISM period, the precipitation could increase by up to $25 \%$ in South Asia and on the Tibetan Plateau (Ji et al., 2011).

\subsection{Diurnal variation of atmospheric $\mathrm{Hg}$ species in QNNP}

During the PISM period, all of the atmospheric $\mathrm{Hg}$ species showed clear diurnal patterns (Fig. 3, Fig. S3). For GEM, the minimum concentrations usually occurred at $\sim 12: 00 \mathrm{UTC}+6\left(0.84 \pm 0.11 \mathrm{ng} \mathrm{m}^{-3}\right)$, while maximum values occurred before dawn $\left(1.98 \pm 0.51 \mathrm{ng} \mathrm{m}^{-3}\right.$ at $\sim$ 05:30 UTC+6). During the afternoon, the GEM concentration increased consistently and reached a peak at sunrise (with a value of $1.98 \mathrm{ng} \mathrm{m}^{-3}$ ). Unlike the daily GEM changes, the GOM and PBM concentrations usually reached maximum concentrations from $\sim 10: 00$ to $\sim 16: 00 \mathrm{UTC}+6$, and the concentrations remained relative stable for the rest of the day. During the ISM period, the diurnal variation of atmospheric $\mathrm{Hg}$ species was less pronounced compared with the values during the PISM period. At different stages of the ISM period, the diurnal pattern was also different. The GEM diurnal variation value (peak value minus lowest value in the same period) decreased over time, from $1.03 \mathrm{ng} \mathrm{m}^{-3}$ during the initial ISM period to $0.43 \mathrm{ng} \mathrm{m}^{-3}$ during the final ISM period. For GEM concentrations during the ISM period, the minimum values all occurred at $\sim 14: 00 \mathrm{UTC}+6$ and the maximum values were observed at $\sim 06: 00 \mathrm{UTC}+6$. After sunrise, the GEM concentrations decreased continuously to lower values at noon.

Compared with the diurnal profiles of GEM from previous studies, the diurnal tendency in QNNP is unique (Table 2). For the sampling sites in other studies, the highest GEM concentrations were usually observed during the day (Nair et al., 2012; Fu et al., 2008; Mukherjee et al., 2009; Karthik et al., 2017; Jen et al., 2014). Kellerhals et al. (2003) reported that the majority of monitoring sites in CAMNet display a common pattern with the maximum concentrations around noon and minimum concentrations before sunrise. Compared with other observation stations and considering QNNP as a remote region with high altitude, a sparse population and rare industry, the results observed here may indicate a simple mechanism of variation in GEM concentration without the complex effect of human activities. Previous studies have suggested that the planetary boundary layer (PBL) could have significant effects on the concentrations of atmospheric pollutants near the ground (Han et al., 2009; Tie et al., 2007; Quan et al., 2013). With a large glacier coverage $\left(\sim 2710 \mathrm{~km}^{2}\right)$, the structure of the boundary layer over the QNNP was significantly affected by glacier winds ( $\mathrm{Li}$ et al., 2006). The local PBL may be subject to impacts from the glacier-covered environment and have a significant diurnal variation. The height of the atmospheric boundary layer could vary significantly from $\sim 350 \mathrm{~m}$ a.g.l. to $\sim 2000 \mathrm{~m}$ a.g.l. in 1 day (Li et al., 2006). Following sunrise, with the strengthening of the glacier wind, a strong convection current starts to grow in the troposphere, and the stock of GEM in the near-ground at- 
Table 1. Statistical metrics of GEM, GOM, PBM and meteorological variables at the Qomolangma National Nature Preserve. $T$ : temperature, RH: relative humidity, WS: wind speed.

\begin{tabular}{|c|c|c|c|c|c|c|c|}
\hline Period & Statistics & $\begin{array}{r}T \\
\left({ }^{\circ} \mathrm{C}\right)\end{array}$ & $\begin{array}{l}\mathrm{RH} \\
(\%)\end{array}$ & $\begin{array}{r}\text { WS } \\
\left(\mathrm{m} \mathrm{s}^{-1}\right)\end{array}$ & $\begin{array}{r}\text { GEM } \\
\left(\mathrm{ng} \mathrm{m}^{-3}\right)\end{array}$ & $\begin{array}{r}\mathrm{GOM} \\
\left(\mathrm{pg} \mathrm{m}^{-3}\right)\end{array}$ & $\begin{array}{r}\mathrm{PBM} \\
\left(\mathrm{pg} \mathrm{m}^{-3}\right)\end{array}$ \\
\hline \multirow{6}{*}{ PISM } & Minimum & -5.6 & 1 & 0 & 0.54 & 11.9 & 9.8 \\
\hline & 1 st qu. & 1.6 & 11 & 1.8 & 0.99 & 21.7 & 22.3 \\
\hline & Median & 6.4 & 25 & 3.6 & 1.19 & 29.5 & 26.8 \\
\hline & Mean & 6.1 & 33 & 4.1 & 1.31 & 35.2 & 30.4 \\
\hline & 3rd qu. & 11.2 & 53 & 6.3 & 1.58 & 42.8 & 36.0 \\
\hline & Maximum & 16.3 & 89 & 13.9 & 2.91 & 101.3 & 92.6 \\
\hline \multirow{6}{*}{ ISM1 } & Min & -3.8 & 9 & 0 & 0.15 & 7.5 & 9.5 \\
\hline & 1 st qu. & 1.6 & 33 & 1.3 & 1.20 & 15.2 & 17.0 \\
\hline & Median & 5.6 & 49 & 2.2 & 1.38 & 19.2 & 19.2 \\
\hline & Mean & 5.6 & 50 & 2.7 & 1.44 & 20.3 & 21.2 \\
\hline & 3rd qu. & 9.8 & 65 & 3.6 & 1.63 & 24.1 & 24.5 \\
\hline & $\operatorname{Max}$ & 15.7 & 91 & 10.3 & 2.74 & 64.0 & 59.1 \\
\hline \multirow{6}{*}{ ISM2 } & Min & -1.3 & 3 & 0 & 0.47 & 4.4 & 12.7 \\
\hline & 1 st qu. & 4.1 & 30 & 1.3 & 1.14 & 18.6 & 40.4 \\
\hline & Median & 8.5 & 48 & 2.2 & 1.35 & 23.9 & 54.8 \\
\hline & Mean & 8.8 & 46 & 3.0 & 1.45 & 25.5 & 53.4 \\
\hline & 3rd qu. & 13.7 & 64 & 4 & 1.68 & 31.3 & 64.9 \\
\hline & $\operatorname{Max}$ & 19.6 & 87 & 11.2 & 3.74 & 63.4 & 106.3 \\
\hline \multirow{6}{*}{ ISM3 } & Min & 2.6 & 26 & 0 & 0.78 & 3.6 & 1.1 \\
\hline & 1 st qu. & 8.1 & 44 & 1.3 & 1.33 & 14.7 & 12.7 \\
\hline & Median & 11.8 & 58 & 2.7 & 1.51 & 19.0 & 17.2 \\
\hline & Mean & 12.0 & 58 & 2.9 & 1.56 & 19.3 & 16.9 \\
\hline & 3rd qu. & 15.6 & 73 & 4 & 1.72 & 23.3 & 21.3 \\
\hline & Max & 21.8 & 92 & 9.9 & 2.70 & 36.6 & 31.3 \\
\hline \multirow{6}{*}{ ISM4 } & Min & 6.0 & 25 & 0 & 0.66 & 7.1 & 0.5 \\
\hline & 1 st qu. & 9.3 & 43 & 1.3 & 1.35 & 13.2 & 10.9 \\
\hline & Median & 12.1 & 61 & 2.7 & 1.46 & 18.1 & 17.4 \\
\hline & Mean & 13.0 & 58 & 2.9 & 1.51 & 21.1 & 20.0 \\
\hline & 3rd qu. & 16.6 & 72 & 3.6 & 1.61 & 24.9 & 26.1 \\
\hline & Max & 22.7 & 90 & 9.9 & 2.62 & 149.1 & 78.6 \\
\hline \multirow{6}{*}{ ISM5 } & Min & 2.2 & 18 & 0 & 0.48 & 1.1 & 0.3 \\
\hline & 1 st qu. & 8.3 & 59 & 0.9 & 1.17 & 7.6 & 6.6 \\
\hline & Median & 10.7 & 75 & 2.2 & 1.35 & 11.0 & 9.8 \\
\hline & Mean & 11.4 & 72 & 2.3 & 1.32 & 12.6 & 11.0 \\
\hline & 3rd qu. & 14.1 & 86 & 3.1 & 1.49 & 16.2 & 14.3 \\
\hline & $\operatorname{Max}$ & 22.9 & 96 & 9.4 & 2.45 & 121.3 & 33.2 \\
\hline
\end{tabular}

mosphere is quickly depleted, leading to the rapid decrease in concentrations. In contrast, after sunset, with the weakening of the glacier wind, the nocturnal stable boundary layer takes a dominate position controlling the surface layer, and its height is relatively low ( $\mathrm{Li}$ et al., 2006), which could lead to increases in GEM concentrations.

Comparing the diurnal variations between the PISM and ISM periods, the atmospheric $\mathrm{Hg}$ concentrations almost show the same pattern. However, the magnitude of the variation during the ISM period is lower relative to the PISM period, and the variation becomes even smaller in the later stages of the ISM (Fig. 3). The GEM concentration usually peaked at $\sim$ 05:00-06:00 UTC+6. in both the PISM and ISM periods. While the peak GEM concentrations were almost at the same level throughout the whole period, the decreasing diurnal variations were mainly due to the increasing GEM concentrations in the afternoon. The increased GEM concentrations in the afternoon may indicate new GEM sources in the ISM period. One possible source of GEM in the afternoon might be $\mathrm{Hg}(0)$ reemission from the glaciers. Holmes et al. (2010) reported that snow-covered land could be a reservoir for the conversion of oxidized $\mathrm{Hg}$ to $\mathrm{Hg}(0)$ under sun- 

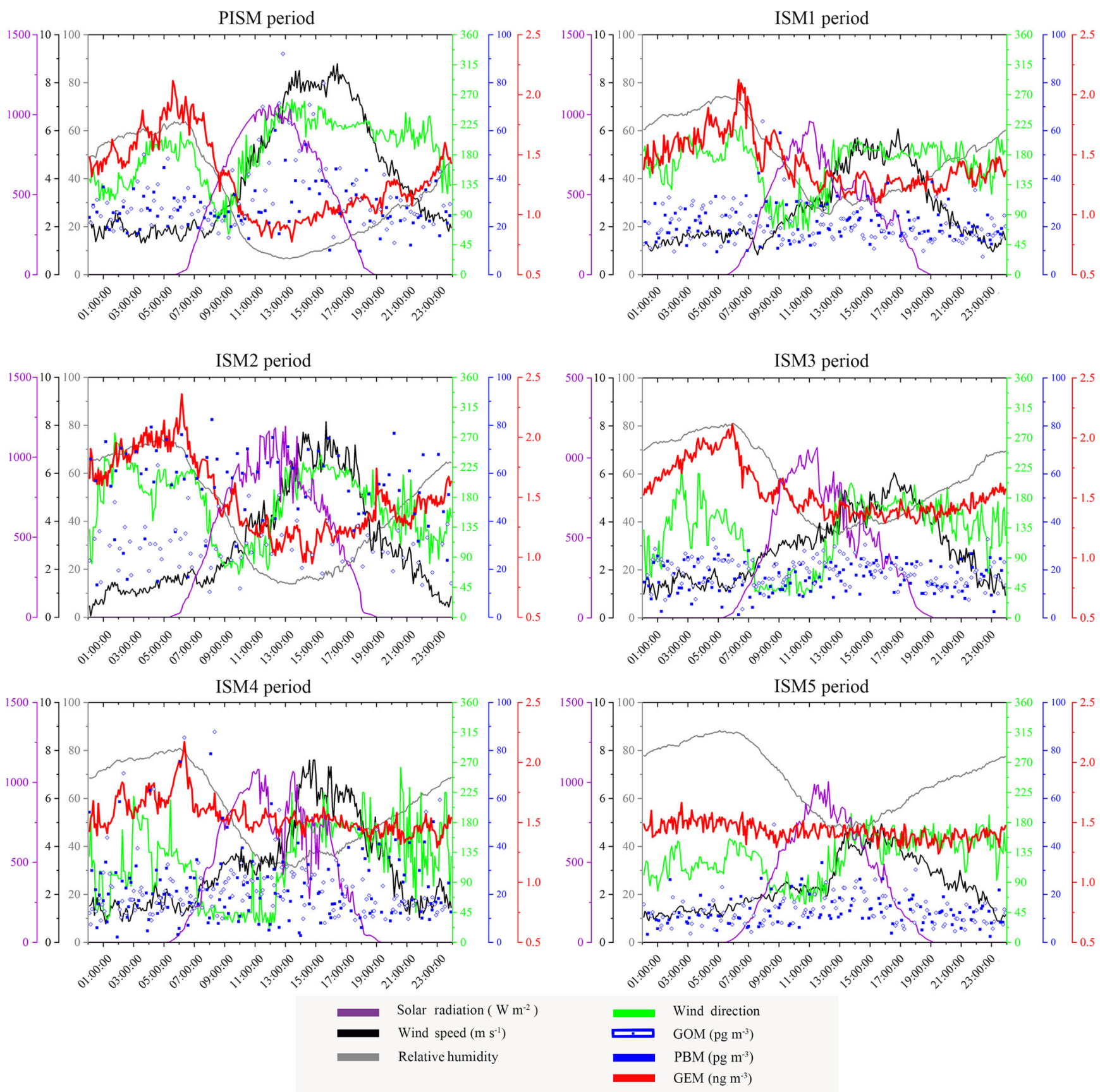

Figure 3. Diurnal variations of GEM, GOM and PBM concentrations during the pre-Indian summer monsoon (PISM) period and the five Indian summer monsoon (ISM) periods: 15-30 April 2016 (PISM), 1-12 May (ISM1), 13 May-4 June (ISM2), 5-20 June (ISM3), 21 June10 July (ISM4) and 11 July-14 August (ISM5). The concentrations represent the daily average values during each period.

light, and approximately $60 \%$ of the $\mathrm{Hg}$ deposited to snow cover could eventually be reemitted to the air. A shorter reservoir lifetime for deposited $\mathrm{Hg}$ in snowpack was also reported when the temperature rises (Faïn et al., 2007). With the increase in ambient temperature and radiation from April to August, the reemission of GEM from the glaciers could also increase. As the snow coverage in the QNNP decreases significantly from the PISM to the ISM period (Fig. S4), some of the released $\mathrm{Hg}$ may become a source of new GEM from the initial ISM phase to the final stage of the ISM period. More $\operatorname{Hg}(0)$ could be released due to the higher temperature and stronger radiation in the afternoon. However, some other factors such as changes in the PBL height and wind directions could also be partly responsible for the diurnal variations of GEM concentrations (Horowitz et al., 2017; Travnikov et al., 2017; Selin, 2009; Li et al., 2006). 
PISM

(a) GEM

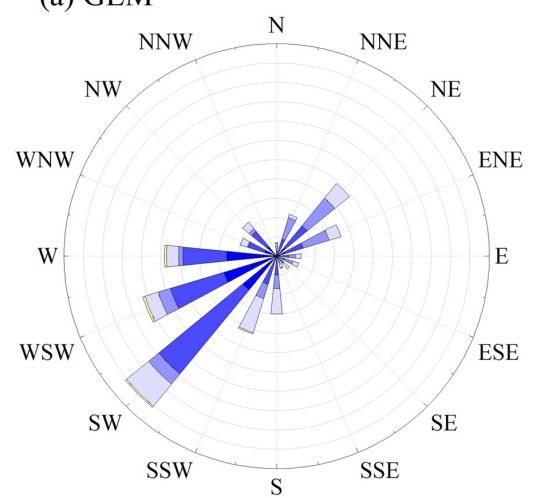

(c) GOM
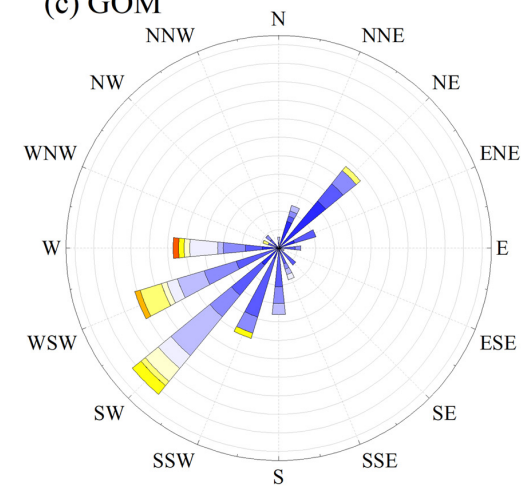

(e) PBM

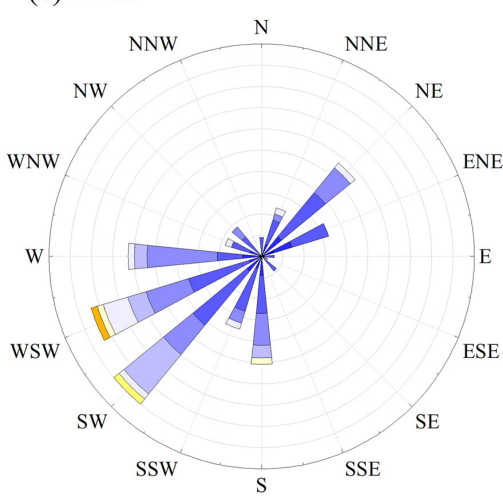

ISM

(b) GEM

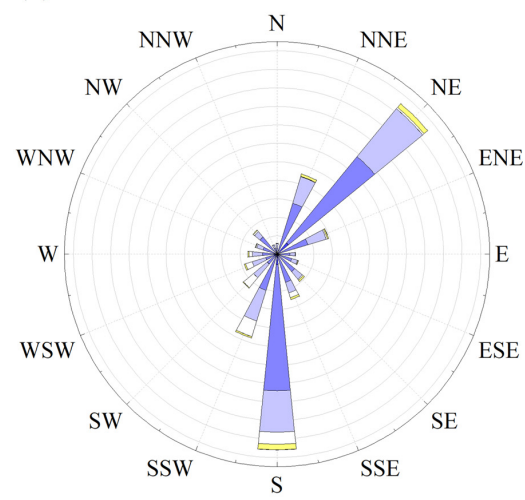

(d) GOM

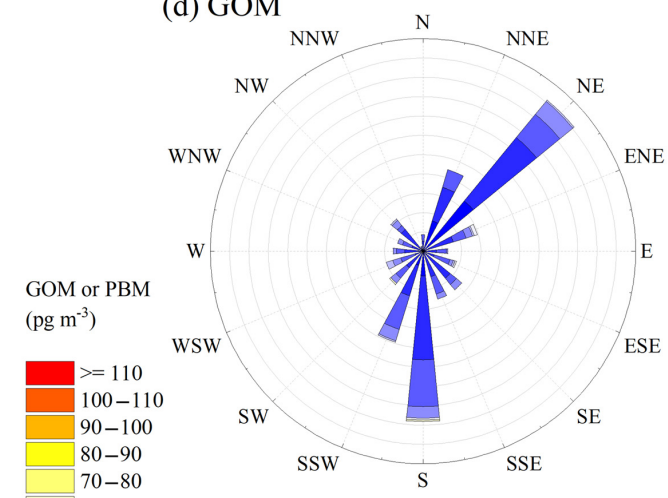

(f) PBM

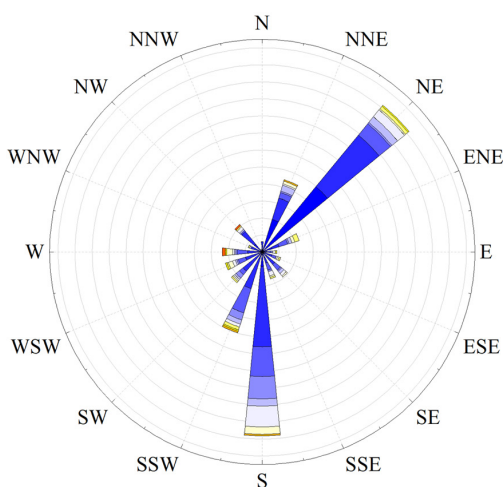

Figure 4. Concentration roses of GEM, GOM and PBM from different wind directions. The length of each spoke describes the frequency of flow from the corresponding direction.

\subsection{Source identification for atmospheric $\mathrm{Hg}$ in the QNNP}

\subsubsection{Wind direction dependence of $\mathrm{Hg}$ concentrations}

Figure 4 shows the concentration roses for GEM, GOM and $\mathrm{PBM}$ at the sampling site during the PISM and ISM periods, respectively. All concentrations of the three species have a strong dependence on the wind direction. During the PISM period, the predominant wind directions with $\mathrm{Hg}$ masses are northeast and southwest. Wind from the northeast of the QNNP originates from and/or passes through other parts of China. The southwest wind, which is the dominant direction and contains the largest amount of $\mathrm{Hg}$, potentially brought air masses from India and Nepal to QNNP. During the ISM period, the predominant wind directions with $\mathrm{Hg}$ masses changed to the south and northeast. Considering the transport rates of $\mathrm{Hg}$ species concentrations (length of sector) from different directions, both directions may have greatly contributed to the $\mathrm{Hg}$ concentration in QNNP, while the air 


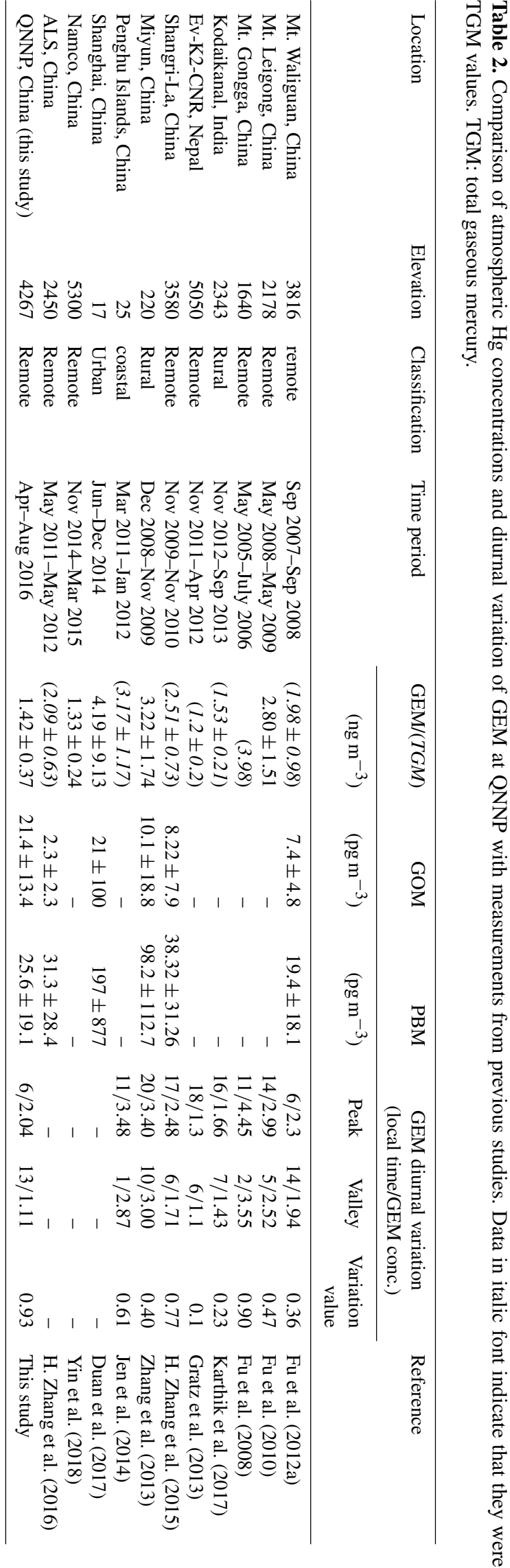

masses from the south brought relatively larger amounts of GOM and PBM.

Relatively low GEM concentrations $\left(<1.5 \mathrm{ng} \mathrm{m}^{-3}\right)$ were observed in most of the samples $(80.0 \%)$ of air masses in the predominant Hg-transport direction (from southwest to west) during the PISM period, which is due to the control of westerlies. With high wind speeds (Table 1) and coming from the direction of central Asia, the westerlies are the predominant wind containing low pollutant levels that spread in the QNNP during the PISM period (Kotlia et al., 2015). Relatively high GEM concentrations $\left(>1.5 \mathrm{ng} \mathrm{m}^{-3}\right)$ were found in $92.4 \%$ of the samples of the predominant $\mathrm{Hg}$ direction during the ISM period under the control of the monsoon (Kotlia et al., 2015), which might indicate that the transported air masses are originating from polluted regions. GOM and PBM displayed similar patterns under the control of the westerlies and monsoon during the PISM and ISM periods, respectively.

\subsubsection{Air mass back trajectory analysis}

To further quantify the contributions of different sources to the GEM concentrations, an air mass back trajectory simulation and trajectory cluster analyses were applied in this study. Figure 5 provides the trajectory clusters of GEM during the PISM and ISM periods. According to the total spatial variation index, all the trajectories in different periods were grouped into three to six clusters. During the PISM period (Fig. 5a), the GEM concentration from cluster 1 (with a frequency of $12 \%$ ) was the highest $\left(1.32 \mathrm{ng} \mathrm{m}^{-3}\right)$, with this cluster originating from or passing through central Asia and northern India. Cluster $2(30 \%)$ and cluster $4(17 \%)$ represented air masses that passed through northern India and northwestern Nepal. According to the local $\mathrm{Hg}$ emission inventory (AMAP/UNEP, 2013), $\mathrm{Hg}$ in this air mass most likely originated from central Pakistan and northern India. Cluster $3(41 \%)$ represented the air masses that originated from or passed through different cities in northern India. Based on the previous atmospheric $\mathrm{Hg}$ emission inventories (Simone et al., 2016; AMAP/UNEP, 2013), Hg emissions in western Asia and central Asia are not significant. Based on a combination of the pathway analysis, emission inventory and GEM concentrations during the PISM period, almost all of the GEM transported by air masses to the QNNP was from northern India and passed through Nepal.

During the ISM period (Fig. 5b-f), the transport pathways of atmospheric $\mathrm{Hg}$ changed significantly with the onset of the monsoon and differed strongly from the PISM period. During the ISM1 period (Fig. 5b), the onset of the ISM was under development, leading to scattered clusters. GEM levels in cluster $2(23 \%)$ were the highest $\left(1.52 \mathrm{ng} \mathrm{m}^{-3}\right)$, with air masses originating from or passing through the Tibetan Plateau. The high GEM concentrations could possibly have resulted from the $\mathrm{Hg}$ emissions from the burning of yak dung (Xiao et al., 2015; Chen et al., 2015; Rhode et al., 2007; Huang et al., 2016). Cluster 1 (17\%) and cluster 3 
(a) PISM period

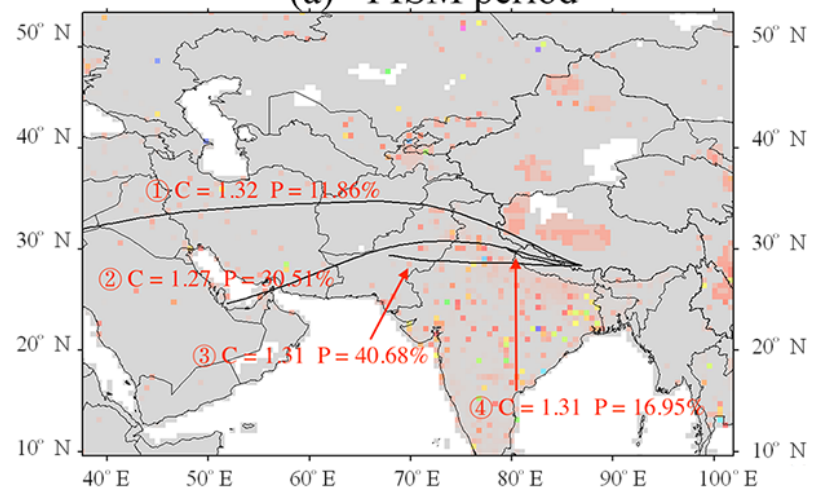

(c) ISM2 period

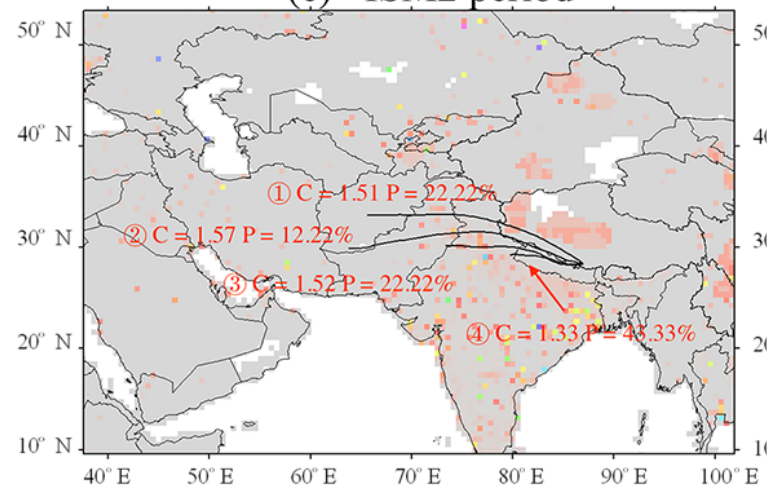

(e) ISM4 period

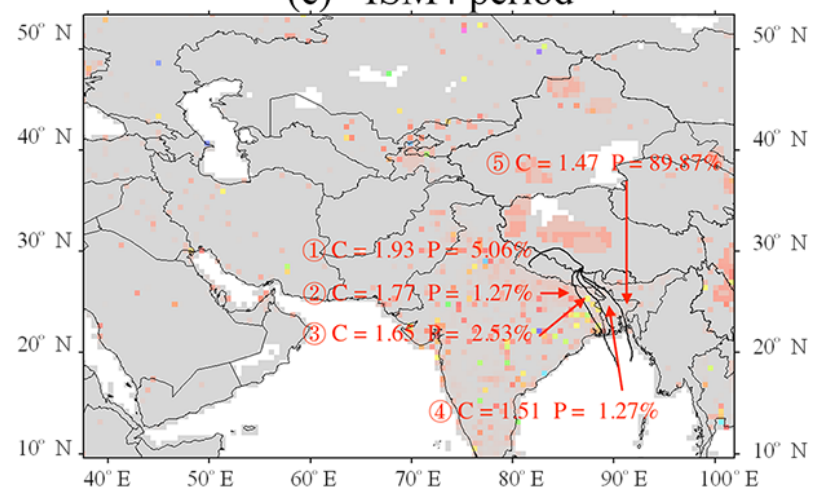

(b) ISM1 period

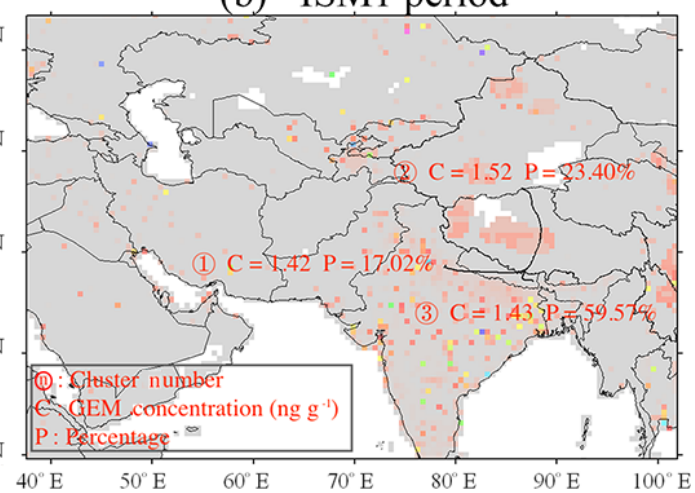

(d) ISM3 period

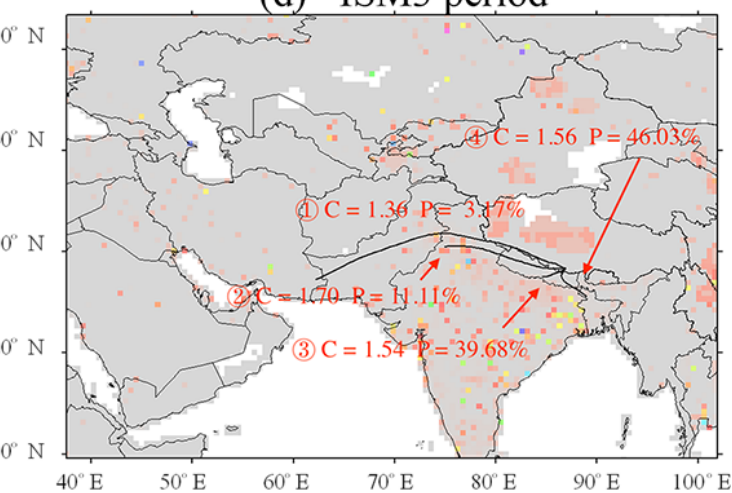

(f) ISM5 period

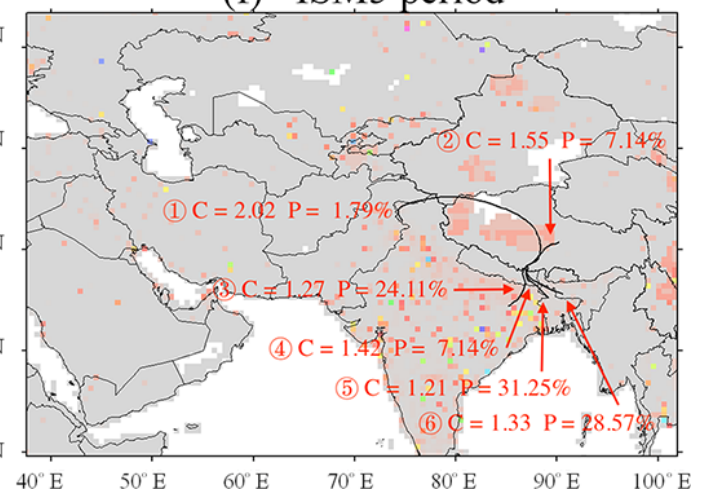

Figure 5. Clusters of the back trajectory analysis from the Qomolangma National Nature Preserve (QNNP) monitoring site during the preIndian summer monsoon (PISM) period and the five Indian summer monsoon (ISM) periods. The cluster statistics summarize the percentage of back trajectories for each cluster. The background shading represents the global $\mathrm{Hg}$ emissions from anthropogenic sources (AMAP/UNEP, 2013).

(60\%) represent the pollutant coming from Nepal, and the trajectory is relatively short. During the ISM2 period, all of the clusters originated from or passed through central Asia, northern India and northwestern Nepal (Fig. 5c). The clusters were similar to most of the clusters during the PISM period; however, the GEM concentrations in these clusters were higher than those during the PISM period, which might have been caused by the large $\mathrm{Hg}$ emissions from frequent fires in the source region during ISM2 (Finley et al., 2009;
Fig. S5). During the ISM3 period (Fig. 5d), most of the clusters moved from the west to the south of the QNNP. Cluster 4 $\left(1.56 \mathrm{ng} \mathrm{m}^{-3}, 46 \%\right)$ represents the pollutant coming from Bangladesh and passing through southeastern Nepal. Cluster $3\left(1.54 \mathrm{ng} \mathrm{m}^{-3}, 40 \%\right)$ originated from or passed through central Nepal. The share of the air masses coming from central Asia, northern India and northwestern Nepal dropped to approximately $14 \%$. During the ISM4 period (Fig. 5e), the clusters moved further west to Bangladesh and eastern In- 
dia. Except for cluster $1(5 \%)$, the other clusters originated from or passed through Bangladesh, eastern India and northeastern Nepal. The conditions during the ISM5 period were almost the same as the ISM4 period: most of the pollutants came from Bangladesh and eastern India and passed through southeastern Nepal.

PSCF models were also applied to identify potential sources by combining the backward trajectory simulations and $\mathrm{Hg}$ monitoring concentrations. Figure 6 shows the regional contributions of GEM emission sources during the PISM period and the ISM period (ISM1-5). During the PISM period (Fig. 6a), most of the Hg sources were in Pakistan, northern India and central Nepal (H. Zhang et al., 2015). The QNNP was most likely impacted by the $\mathrm{Hg}$ emissions from Karachi, Lahore (Pakistan), New Delhi, Uttar Pradesh (India), Katmandu and Pokhara (Nepal), all of which are large urban regions with intensive industrial activities. With the development of the ISM, the potential sources gradually shifted from western Nepal to eastern Nepal and Bangladesh (Fig. 6b-f). The PSCF analysis indicated that the air masses could have been transboundary transport events from Pakistan, India, Nepal and Bangladesh to QNNP.

Atmospheric $\mathrm{Hg}$ clusters during both the PISM and ISM periods indicated that the air masses, which originated from or passed through northern India and Nepal, would have made great contributions to the $\mathrm{Hg}$ concentration in the QNNP. Northern India and Nepal were also identified as potential source regions for the QNNP. Clusters 2-4 of the PISM period represent the air masses from regions outside China, and they show that over $88 \%$ of the GEM in the QNNP was transported from outside China during the PISM period. During the ISM2-5 period, over $95 \%$ of the GEM was transported to the QNNP from regions outside China. Meanwhile, the GEM concentration increased by $10 \%$ from the PISM period to the ISM period according to the site monitoring data, indicating an increasing amount of transported GEM. According to the United Nations Environment Programme (UNEP) Hg emission inventory (AMAP/UNEP, 2013), northern India is an important $\mathrm{Hg}$ source which might be responsible for the transboundary transportation of $\mathrm{Hg}$ to China (Fig. 5), and the growing emissions in India are related to the rapidly growing economy and increasing usage of fossil fuels (Sharma, 2003). Considering the heavy air pollution in Nepal (Rupakheti et al., 2017; Forouzanfar et al., 2015) and Bangladesh (Islam et al., 2015; Rahman et al., 2018; Rana et al., 2016; Mondol et al., 2014), Nepal and Bangladesh might be underestimated $\mathrm{Hg}$ source regions in the modeling and should be taken into consideration in further study.

Under the control of the ISM during the ISM2 period, the high PBM concentration may be related to biomass burning in the source region. According to the PSCF analysis, northern India and Nepal are the potential source regions during the ISM2 period. The source identification by back trajectory simulation and trajectory cluster analyses also indicated that northern India and Nepal are in the air mass transport trajectory that would transport $\mathrm{Hg}$ to the QNNP. Finley et al. (2009) reported that PBM concentrations could be associated with $\mathrm{Hg}$ emissions from wildfire events. Therefore, one possible cause of the high PBM concentration observed is the frequent fire events that occurred during the ISM2 period in the trajectory of these air masses. Figure S4 shows the fire hotspots observed by MODIS from April to August 2016. During the ISM2 period, frequent fire hotspots were identified in the source region, and large amounts of PBM may have been released into the atmosphere from biomass burning (Finley et al., 2009). The transport of those air masses with enriched PBM was controlled by the ISM and intensified by glacier winds. The transport of polluted air to QNNP resulted in the spike in the PBM concentration during the ISM2 period. During the PISM period, although the number of fire hotspots was much higher, most of the fire hotspot locations were not in the potential source region (Fig. 6a, Fig. S4), resulting in the low PBM concentration observed.

\subsection{Implications from this study}

Due to its high altitude and remote location deep on the southern Tibetan Plateau, the QNNP is isolated from anthropogenic perturbations and industrial activities; therefore, this area was thought to be shielded from pollutant inputs from South Asia. However, our results show that the $\mathrm{Hg}$ concentration in this region is not as low as previously expected. During the whole monitoring period, the highest GEM concentration reached $3.74 \mathrm{ng} \mathrm{m}^{-3}$ (with trajectories passing through the north of India), which was $\sim 2.5$ times higher than the average concentration in the Northern Hemisphere $\left(\sim 1.5\right.$ to $\left.1.7 \mathrm{ng} \mathrm{m}^{-3}\right)$ (Lindberg et al., 2007; Slemr et al., 2015; Venter et al., 2015). The average GEM concentration in the middle of the ISM period was $1.56 \mathrm{ng} \mathrm{m}^{-3}$, which is inside the average range of observed Northern Hemisphere GEM concentrations. Compared with the ISM period, the GEM concentrations in the PISM period were significantly lower, with a value of $1.31 \pm 0.42 \mathrm{ng} \mathrm{m}^{-3}$. This value during the PISM is not high compared with other background monitoring data in the Northern Hemisphere.

We now recognize that transboundary transportation is an important mechanism that can influence $\mathrm{Hg}$ distribution in this region. In particular, the air masses transported to the QNNP might be primarily under the control of mesoscale ISM drivers and intensified by regional glacier winds (Fig. 7). From the PISM period to the ISM period, the warm center gradually shifts northwestward from low latitudes to the QNNP (Wang et al., 2001; Ge et al., 2018), and the South Asian high moves onto the Tibetan Plateau and maintains a strong upper-level divergence and upward motion. The upward motion makes the air masses cross the high-altitude Himalayan Mountains and move to mainland China (Xu et al., 2009; Bonasoni et al., 2010). During the ISM period, the transboundary transport of atmospheric $\mathrm{Hg}$ 
(a) PISM period

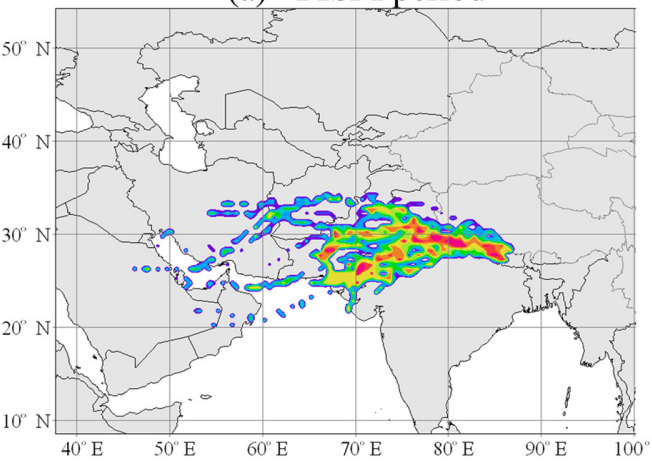

(c) ISM2 period

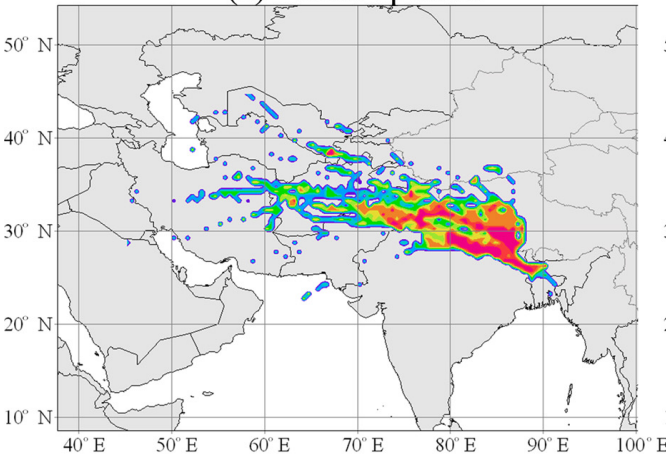

(e) ISM4 period

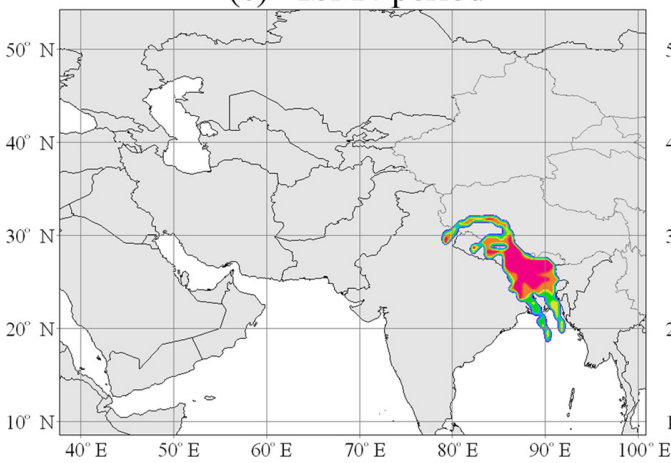

(b) ISM1 period

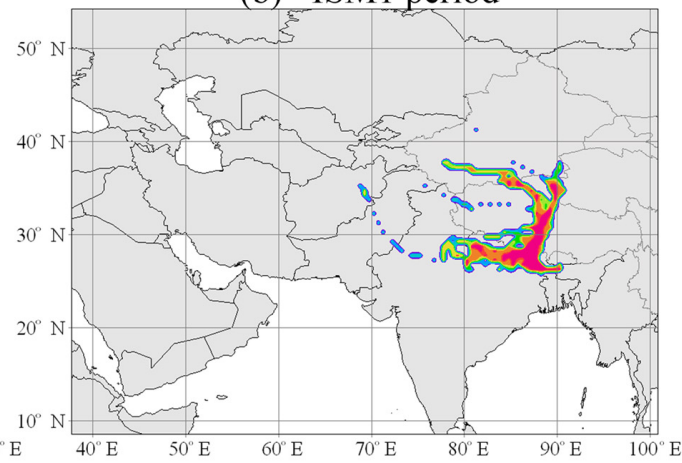

(d) ISM3 period

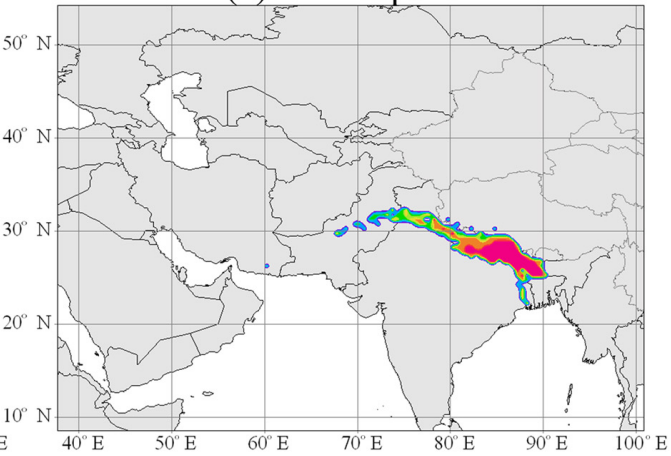

(f) ISM5 period

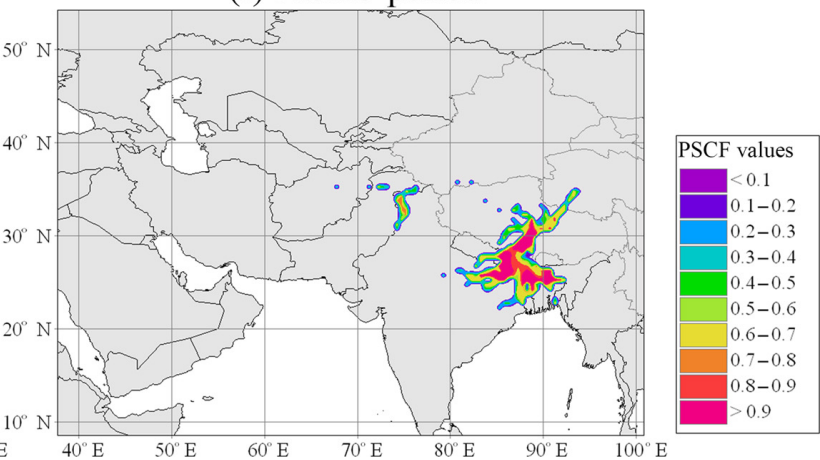

Figure 6. Potential source regions and pathways of GEM using the potential source contribution function (PSCF) method before and during the Indian summer monsoon (ISM). PSCF values represent the probability that a grid cell is a source of $\mathrm{Hg}$.

is strengthened by both monsoon and glacial winds; however, this effect seems to be weaker during the PISM period. The transboundary transported air masses can be pumped down right after crossing Mt. Qomolangma due to the control of the regionally unique wind transportation mode, the glacier wind. Hence, in addition to the monsoon, the transboundary transport of $\mathrm{Hg}$ could also be intensified by regional glacier winds, leading to the increases of atmospheric $\mathrm{Hg}$ in this region. As shown in other studies on the northern or eastern Tibetan Plateau, the glacier wind can pump air masses down from upper levels to the surface in the QNNP (Cai et al., 2007). This pump movement is remarkably efficient at transporting air masses (Zhu et al., 2006), and could bring a significant amount of pollutants to QNNP.
In 2013, the Minamata Convention on Mercury was developed to control global $\mathrm{Hg}$ pollution. Atmospheric $\mathrm{Hg}$ has been reported to have continuously declined $(\sim 1-$ $2 \%$ year $^{-1}$ ) at the monitoring sites in North America and Europe since 1990 (Y. Zhang et al., 2016). Under the convention, a National Implementation Plan on Mercury Control has been developed in China to fulfill the commitment to control and reduce $\mathrm{Hg}$ emissions (World Bank, 2016). Average GEM concentrations in East China decreased from $2.68 \pm 1.07 \mathrm{ng} \mathrm{m}^{-3}$ in 2014 to $1.60 \pm 0.56 \mathrm{ng} \mathrm{m}^{-3}$ in 2016 (Tang et al., 2018). According to the recently updated emission inventory in China (Wu et al., 2016), anthropogenic $\mathrm{Hg}$ emissions in the country reached a peak amount of about 567 tonnes in 2011 and have decreased since then. In 2014, 


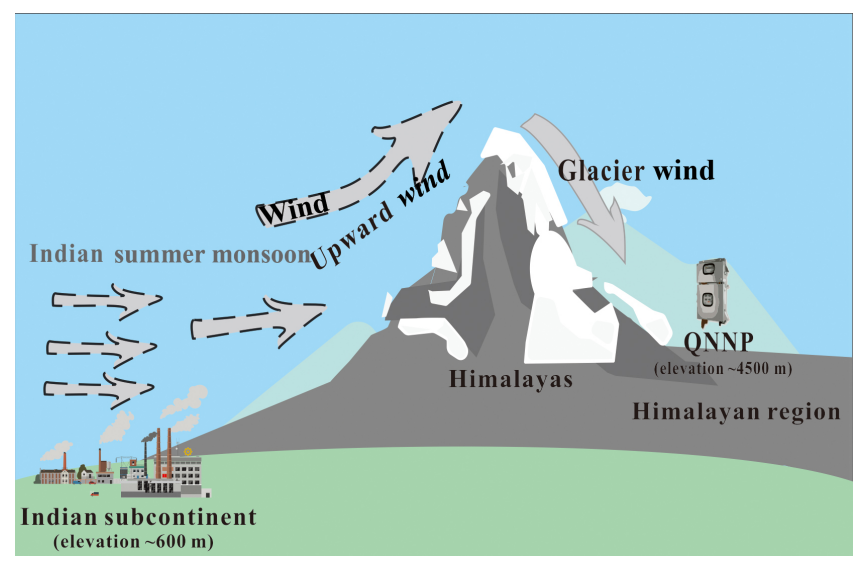

Figure 7. Conceptual map of the transboundary transport of atmospheric $\mathrm{Hg}$ in the Himalayan region. Arrows show the impacts of the Indian summer monsoon, upward winds and glacial winds on the transboundary transport of $\mathrm{Hg}$.

the anthropogenic $\mathrm{Hg}$ emissions decreased to 530 tonnes. This was also confirmed in the concentration of plant $\mathrm{Hg}$ from a sampling site near the QNNP, which recorded the decrease of atmospheric $\mathrm{Hg}$ concentrations in Tibet since the year of 2010 (Tong et al., 2016). However, the source identity analysis in QNNP indicates that foreign regions outside China were the main contributor responsible for the observed pollutants (accounting for $95 \%$ of the whole trajectory during the main ISM period). This result indicates that the $\mathrm{Hg}$ concentration in QNNP would not really benefit from China's efforts toward $\mathrm{Hg}$ reductions. South Asian developing countries (e.g., India, Nepal and Bangladesh) (Streets et al., 2011; R. Zhang et al., 2015; Yang et al., 2018) seem to be the key to controlling atmospheric $\mathrm{Hg}$ concentrations in QNNP. Hg emissions in India were estimated to be approximately 310 tonnes in 2010 and are predicted to rise to 540 tonnes in 2020 (Burger Chakraborty et al., 2013). India, Nepal and Bangladesh have all signed the Minamata Convention, although only the Indian government has ratified the convention so far. It is urgent for the abovementioned countries to take immediate actions to reduce $\mathrm{Hg}$ emissions, which is crucial for reducing atmospheric $\mathrm{Hg}$ concentrations in QNNP.

\section{Conclusions}

A comprehensive investigation of the concentrations, origin and transport of GEM, GOM and PBM was undertaken in QNNP. This region is a remote, high-altitude station located at the boundary between the Indian subcontinent and the Tibetan Plateau and in the transport pathway of the Indian summer monsoon from South Asia to the Tibetan Plateau. The average GEM concentration $\left(1.31 \pm 0.42 \mathrm{ng} \mathrm{m}^{-3}\right)$ during the PISM period was lower than that during the ISM period $\left(1.44 \pm 0.36 \mathrm{ng} \mathrm{m}^{-3}\right)$. The average GOM and PBM concentrations during the PISM period were higher than those during the ISM period, which might have been be related to the increasing wet deposition during the ISM period. The average GOM concentration was higher than that found in most rural areas in the US and China. The GEM concentration had a significant diurnal variation pattern in the QNNP, with the maximum GEM concentration observed before sunrise and a sharp decrease noted after sunrise until noon. The magnitude of the diurnal variation declined from April to August, which could be related to the reemission of $\mathrm{Hg}$ from snow cover and change in the PBL.

According to the backward trajectory analysis and cluster analysis, most of the air masses with high GEM concentrations in QNNP originated from or passed through Bangladesh, northern India and central Nepal. Using PSCF analysis, we found that Pakistan, northern India and Nepal are potential source regions during the PISM period, and Bangladesh, northern India and Nepal were identified as outbound potential sources during the ISM period. During the ISM period, the air masses were able to cross the highaltitude Himalayan Mountains with the help of the ISM. Once the air masses passed over the Himalayas, they could be brought into the surface layer and transported to QNNP by the constant daytime downslope glacier wind. As $\mathrm{Hg}$ is easily transported long distances via the atmosphere, the nations in South Asia must work together to develop and apply appropriate pollutant reduction strategies to reduce atmospheric Hg emissions.

Data availability. All the data presented in this paper can be made available for scientific purposes upon request to the corresponding authors Yindong Tong (yindongtong@tju.edu.cn) and Xuejun Wang (wangxuejun@pku.edu.cn).

Supplement. The supplement related to this article is available online at: https://doi.org/10.5194/acp-19-1373-2019-supplement.

Author contributions. XW, YT, HL, QZ and XY designed the research and performed field measurements. HL and YT performed the data analysis and model simulations. HL, YT and Bd led the paper writing. HZ, HZ, LC, SK, WZ, JS and XB contributed to the scientific discussion and the paper preparation.

Competing interests. The authors declare that they have no conflict of interest.

Acknowledgements. This study was funded by the National Natural Science Foundation of China (grant nos. 41630748, 41501517 and 41571130010) and the Natural Science Foundation of Tianjin (grant no. 16JCQNJC08300). The authors are grateful to the 
NOAA for providing the HYSPLIT model and GFS meteorological files and to NASA for providing the MODIS files. We also thank the staff of the Atmospheric and Environmental Comprehensive Observation and Research Station of the Chinese Academy of Sciences on Mt. Qomolangma for assistance with field sampling.

Edited by: Ralf Ebinghaus

Reviewed by: two anonymous referees

\section{References}

AMAP/UNEP: Technical Background Report for the Global Mercury Assessment 2013, Arctic Monitoring and Assessment Program, 2013.

Ambrose, J. L.: Improved methods for signal processing in measurements of mercury by $\operatorname{Tekran}^{\circledR} \quad 2537 \mathrm{~A}$ and 2537B instruments, Atmos. Meas. Tech., 10, 5063-5073, https://doi.org/10.5194/amt-10-5063-2017, 2017.

Angot, H., Dion, I., Vogel, N., Legrand, M., Magand, O., and Dommergue, A.: Multi-year record of atmospheric mercury at Dumont d'Urville, East Antarctic coast: continental outflow and oceanic influences, Atmos. Chem. Phys., 16, 8265-8279, https://doi.org/10.5194/acp-16-8265-2016, 2016.

Ashbaugh, L. L., Malm, W. C., and Sadeh, W. Z.: A residence time probability analysis of sulfur concentrations at Grand Canyon National Park, Atmos. Environ., 19, 1263-1270, 1985.

Bolch, T., Kulkarni, A., Kääb, A., Huggel, C., Paul, F., Cogley, J., Frey, H., Kargel, J. S., Fujita, K., and Scheel, M.: The state and fate of Himalayan glaciers, Science, 336, 310-314, 2012.

Bonasoni, P., Laj, P., Marinoni, A., Sprenger, M., Angelini, F., Arduini, J., Bonafé, U., Calzolari, F., Colombo, T., Decesari, S., Di Biagio, C., di Sarra, A. G., Evangelisti, F., Duchi, R., Facchini, MC., Fuzzi, S., Gobbi, G. P., Maione, M., Panday, A., Roccato, F., Sellegri, K., Venzac, H., Verza, G. P., Villani, P., Vuillermoz, E., and Cristofanelli, P.: Atmospheric Brown Clouds in the Himalayas: first two years of continuous observations at the Nepal Climate Observatory-Pyramid (5079 m), Atmos. Chem. Phys., 10, 7515-7531, https://doi.org/10.5194/acp10-7515-2010, 2010.

BP Statistical Review of World Energy: BP statistical review of world energy June 2018, available at: http://www.bp.com/en/global/corporate/energy-economics/ statistical-review-of-world-energy.html (last access: 7 May 2018), 2018.

Burger Chakraborty, L., Qureshi, A., Vadenbo, C., and Hellweg, S.: Anthropogenic mercury flows in India and impacts of emission controls, Environ. Sci. Technol., 47, 8105-8113, 2013.

Cai, X., Song, Y., Zhu, T., Lin, W., and Kang, L.: Glacier winds in the Rongbuk Valley, north of Mount Everest: 2. Their role in vertical exchange processes, J. Geophys. Res.-Atmos., 112, D11102, https://doi.org/10.1029/2006JD007868, 2007.

Chai, T., Stein, A., Ngan, F., and Draxler, R.: Inverse modeling with HYSPLIT Lagrangian Dispersion Model-Tests and Evaluation using the Cross Appalachian Tracer Experiment (CAPTEX) data, AGUFM, 2016.

Chai, T., Crawford, A., Stunder, B., Pavolonis, M. J., Draxler, R., and Stein, A.: Improving volcanic ash predictions with the HYSPLIT dispersion model by assimilating MODIS satellite retrievals, Atmos. Chem. Phys., 17, 2865-2879, https://doi.org/10.5194/acp-17-2865-2017, 2017.

Chen, G., Li, J., Chen, B., Wen, C., Yang, Q., Alsaedi, A., and Hayat, T.: An overview of mercury emissions by global fuel combustion: the impact of international trade, Renew. Sust. Energ. Rev. 65, 345-355, 2016.

Chen, P., Kang, S., Bai, J., Sillanpää, M., and Li, C.: Yak dung combustion aerosols in the Tibetan Plateau: Chemical characteristics and influence on the local atmospheric environment, Atmos. Res., 156, 58-66, https://doi.org/10.1016/j.atmosres.2015.01.001, 2015.

Chen, P., Gao, Y., Lee, A. T., Cering, L., Shi, K., and Clark, S. G.: Human-carnivore coexistence in Qomolangma (Mt. Everest) Nature Reserve, China: Patterns and compensation, Biol. Conserv., 197, 18-26, 2016.

Chen, W.-K., Li, T.-C., Sheu, G.-R., Lin, N.-H., Chen, L.-Y., and Yuan, C.-S.: Correlation analysis, transportation mode of atmospheric mercury and criteria air pollutants, with meteorological parameters at two remote sites of mountain and offshore island in Asia, Aerosol Air Qual. Res., 16, 2692-2705, 2016.

Das, R., Wang, X., Khezri, B., Webster, R. D., Sikdar, P. K., and Datta, S.: Mercury isotopes of atmospheric particle bound mercury for source apportionment study in urban Kolkata, India, Elem. Sci. Anth., 4, p.98, 2016.

Davies, D. K., Ilavajhala, S., Wong, M. M., and Justice, C. O.: Fire information for resource management system: archiving and distributing MODIS active fire data, IEEE T. Geosci. Remote, 47, 72-79, 2009.

de Foy, B., Tong, Y., Yin, X., Zhang, W., Kang, S., Zhang, Q., Zhang, G., Wang, X., and Schauer, J. J.: First field-based atmospheric observation of the reduction of reactive mercury driven by sunlight, Atmos. Environ., 134, 27-39, 2016.

Duan, L., Wang, X., Wang, D., Duan, Y., Cheng, N., and Xiu, G.: Atmospheric mercury speciation in Shanghai, China, Sci. Total Environ., 578, 460-468, 2017.

Ebinghaus, R., Kock, H., Coggins, A., Spain, T., Jennings, S., and Temme, C.: Long-term measurements of atmospheric mercury at Mace Head, Irish west coast, between 1995 and 2001, Atmos. Environ., 36, 5267-5276, 2002.

Faïn, X., Grangeon, S., Bahlmann, E., Fritsche, J., Obrist, D., Dommergue, A., Ferrari, C. P., Cairns, W., Ebinghaus, R., and Barbante, C.: Diurnal production of gaseous mercury in the alpine snowpack before snowmelt, J. Geophys. Res.-Atmos., 112, 2007.

Faïn, X., Obrist, D., Hallar, A. G., Mccubbin, I., and Rahn, T.: High levels of reactive gaseous mercury observed at a high elevation research laboratory in the Rocky Mountains, Atmos. Chem. Phys., 9, 8049-8060, https://doi.org/10.5194/acp-9-8049-2009, 2009.

Finley, B., Swartzendruber, P., and Jaffe, D.: Particulate mercury emissions in regional wildfire plumes observed at the Mount Bachelor Observatory, Atmos. Environ., 43, 6074-6083, 2009.

Forouzanfar, M. H., Alexander, L., Anderson, H. R., Bachman, V. F., Biryukov, S., Brauer, M., Burnett, R., Casey, D., Coates, M. M., and Cohen, A.: Global, regional, and national comparative risk assessment of 79 behavioural, environmental and occupational, and metabolic risks or clusters of risks in 188 countries, 1990-2013: a systematic analysis for the Global Burden of Disease Study 2013, The Lancet, 386, 2287-2323, 2015. 
Fu, X., Feng, X., Zhu, W., Wang, S., and Lu, J.: Total gaseous mercury concentrations in ambient air in the eastern slope of Mt. Gongga, South-Eastern fringe of the Tibetan plateau, China, Atmos. Environ., 42, 970-979, 2008.

Fu, X. W., Feng, X., Dong, Z. Q., Yin, R. S., Wang, J. X., Yang, Z. R., and Zhang, H.: Atmospheric gaseous elemental mercury (GEM) concentrations and mercury depositions at a high-altitude mountain peak in south China, Atmos. Chem. Phys., 10, 24252437, https://doi.org/10.5194/acp-10-2425-2010, 2010.

Fu, X. W., Feng, X., Liang, P., Deliger, Zhang, H., Ji, J., and Liu, P.: Temporal trend and sources of speciated atmospheric mercury at Waliguan GAW station, Northwestern China, Atmos. Chem. Phys., 12, 1951-1964, https://doi.org/10.5194/acp12-1951-2012, 2012a.

Fu, X. W., Feng, X., Shang, L. H., Wang, S. F., and Zhang, H.: Two years of measurements of atmospheric total gaseous mercury (TGM) at a remote site in Mt. Changbai area, Northeastern China, Atmos. Chem. Phys., 12, 4215-4226, https://doi.org/10.5194/acp-12-4215-2012, 2012b.

Gay, D. A., Schmeltz, D., Prestbo, E., Olson, M., Sharac, T., and Tordon, R.: The Atmospheric Mercury Network: measurement and initial examination of an ongoing atmospheric mercury record across North America, Atmos. Chem. Phys., 13, 1133911349, https://doi.org/10.5194/acp-13-11339-2013, 2013.

Ge, J., You, Q., and Zhang, Y.: The influence of the Asian summer monsoon onset on the northward movement of the South Asian high towards the Tibetan Plateau and its thermodynamic mechanism, Int. J. Climatol., 38, 543-553, 2018.

Giglio, L., Descloitres, J., Justice, C. O., and Kaufman, Y. J.: An enhanced contextual fire detection algorithm for MODIS, Remote. Sens. Environ., 87, 273-282, 2003.

Gratz, L., Esposito, G., Dalla Torre, S., Cofone, F., Pirrone, N., and Sprovieri, F.: First Measurements of Ambient Total Gaseous Mercury (TGM) at the EvK2CNR Pyramid Observatory in Nepal, E3S Web of Conferences, 2013.

Guo, J., Kang, S., Huang, J., Zhang, Q., Rupakheti, M., Sun, S., Tripathee, L., Rupakheti, D., Panday, A. K., and Sillanpää, M.: Characterizations of atmospheric particulate-bound mercury in the Kathmandu Valley of Nepal, South Asia, Sci. Total Environ., 579, 1240-1248, 2017.

Hall, D. K., Riggs, G. A., Foster, J. L., and Kumar, S. V.: Development and evaluation of a cloud-gap-filled MODIS daily snowcover product, Remote Sens. Environ., 114, 496-503, 2010.

Han, S., Bian, H., Tie, X., Xie, Y., Sun, M., and Liu, A.: Impact of nocturnal planetary boundary layer on urban air pollutants: Measurements from a 250-m tower over Tianjin, China, J. Hazard. Mater., 162, 264-269, 2009.

Holmes, C. D., Jacob, D. J., Corbitt, E. S., Mao, J., Yang, X., Talbot, R., and Slemr, F.: Global atmospheric model for mercury including oxidation by bromine atoms, Atmos. Chem. Phys., 10, 12037-12057, https://doi.org/10.5194/acp-10-120372010, 2010.

Horowitz, H. M., Jacob, D. J., Zhang, Y., Dibble, T. S., Slemr, F., Amos, H. M., Schmidt, J. A., Corbitt, E. S., Marais, E. A., and Sunderland, E. M.: A new mechanism for atmospheric mercury redox chemistry: implications for the global mercury budget, Atmos. Chem. Phys., 17, 6353-6371, https://doi.org/10.5194/acp17-6353-2017, 2017.
Huang, J., Lyman, S. N., Hartman, J. S., and Gustin, M. S.: A review of passive sampling systems for ambient air mercury measurements, Environ. Sci.-Proc. Imp., 16, 374-392, https://doi.org/10.1039/c3em00501a, 2014.

Huang, J., Kang, S., Guo, J., Zhang, Q., Cong, Z., Sillanpää, M., Zhang, G., Sun, S., and Tripathee, L.: Atmospheric particulate mercury in Lhasa city, Tibetan Plateau, Atmos. Environ., 142, 433-441, 2016.

Hurst, T. and Davis, C.: Forecasting volcanic ash deposition using HYSPLIT, Journal of Applied Volcanology, 6, 5-13, 2017.

Islam, M. F., Majumder, S. S., Al Mamun, A., Khan, M. B., Rahman, M. A., and Salam, A.: Trace metals concentrations at the atmosphere particulate matters in the Southeast Asian Mega City (Dhaka, Bangladesh), Open Journal of Air Pollution, 4, 86-98, 2015.

Jen, Y.-H., Chen, W.-H., Hung, C.-H., Yuan, C.-S., and Ie, I.-R.: Field measurement of total gaseous mercury and its correlation with meteorological parameters and criteria air pollutants at a coastal site of the Penghu Islands, Aerosol Air Qual. Res., 14, 364-375, 2014.

Ji, Z., Kang, S., Zhang, D., Zhu, C., Wu, J., and Xu, Y.: Simulation of the anthropogenic aerosols over South Asia and their effects on Indian summer monsoon, Clim. Dynam., 36, 16331647, 2011.

Kaiser, A., Scheifinger, H., Spangl, W., Weiss, A., Gilge, S., Fricke, W., Ries, L., Cemas, D., and Jesenovec, B.: Transport of nitrogen oxides, carbon monoxide and ozone to the alpine global atmosphere watch stations Jungfraujoch (Switzerland), Zugspitze and Hohenpeißenberg (Germany), Sonnblick (Austria) and Mt. Krvavec (Slovenia), Atmos. Environ., 41, 9273-9287, 2007.

Karthik, R., Paneerselvam, A., Ganguly, D., Hariharan, G., Srinivasalu, S., Purvaja, R., and Ramesh, R.: Temporal variability of atmospheric Total Gaseous Mercury and its correlation with meteorological parameters at a high-altitude station of the South India, Atmos. Pollut. Res., 8, 164-173, 2017.

Kellerhals, M., Beauchamp, S., Belzer, W., Blanchard, P., Froude, F., Harvey, B., McDonald, K., Pilote, M., Poissant, L., and Puckett, K.: Temporal and spatial variability of total gaseous mercury in Canada: results from the Canadian Atmospheric Mercury Measurement Network (CAMNet), Atmos. Environ., 37, 1003 1011, 2003.

Kim, E., Hopke, P. K., Kenski, D. M., and Koerber, M.: Sources of fine particles in a rural midwestern US area, Environ. Sci. Technol., 39, 4953-4960, 2005.

Kotlia, B. S., Singh, A. K., Joshi, L. M., and Dhaila, B. S.: Precipitation variability in the Indian Central Himalaya during last ca. 4000 years inferred from a speleothem record: Impact of Indian Summer Monsoon (ISM) and Westerlies, Quatern. Int., 371, 244-253, 2015.

Landis, M. S., Stevens, R. K., Schaedlich, F., and Prestbo, E. M.: Development and characterization of an annular denuder methodology for the measurement of divalent inorganic reactive gaseous mercury in ambient air, Environ. Sci. Technol., 36, 3000-3009, 2002.

Li, C., Bosch, C., Kang, S., Andersson, A., Chen, P., Zhang, Q., Cong, Z., Chen, B., Qin, D., and Gustafsson, Ö.: Sources of black carbon to the Himalayan-Tibetan Plateau glaciers, Nat. Commun., 7, 12574, https://doi.org/10.1038/ncomms12574, 2016. 
Li, M., Dai, Y., Ma, Y., Zhong, L., and Lu, S.: Analysis on structure of atmospheric boundary layer and energy exchange of surface layer over Mount Qomolangma region, Plateau Meteorology, 25, 807-813, 2006.

Lindberg, S., Bullock, R., Ebinghaus, R., Engstrom, D., Feng, X., Fitzgerald, W., Pirrone, N., Prestbo, E., and Seigneur, C.: A synthesis of progress and uncertainties in attributing the sources of mercury in deposition, AMBIO, 36, 19-33, 2007.

Lindberg, S. A. and Stratton, W.: Atmospheric mercury speciation: concentrations and behavior of reactive gaseous mercury in ambient air, Environ. Sci. Technol., 32, 49-57, 1998.

Lynam, M. M., Dvonch, J. T., Hall, N. L., Morishita, M., and Barres, J. A.: Spatial patterns in wet and dry deposition of atmospheric mercury and trace elements in central Illinois, USA, Environ. Sci. Pollut. R., 21, 4032-4043, 2014.

Mondol, M., Khaled, M., Chamon, A., and Ullah, S.: Trace metal concentration in atmospheric aerosols in some city areas of Bangladesh, J. Sci. Ind. Res., 49, 263-270, 2014.

Mukherjee, A. B., Bhattacharya, P., Sarkar, A., and Zevenhoven, R.: Mercury emissions from industrial sources in India and its effects in the environment, in: Mercury Fate and Transport in the Global Atmosphere, edited by: Mason, R. and Pirrone, N., Springer, 81112,2009

Nair, U. S., Wu, Y., Walters, J., Jansen, J., and Edgerton, E. S.: Diurnal and seasonal variation of mercury species at coastalsuburban, urban, and rural sites in the southeastern United States, Atmos. Environ., 47, 499-508, 2012.

Nie, Y., Zhang, Y., Liu, L., and Zhang, J.: Monitoring glacier change based on remote sensing in the Mt. Qomolangma National Nature Preserve, 1976-2006, Acta Geographica Sinica, 65, 13-28, 2010.

Panthi, J., Dahal, P., Shrestha, M. L., Aryal, S., Krakauer, N. Y., Pradhanang, S. M., Lakhankar, T., Jha, A. K., Sharma, M., and Karki, R.: Spatial and temporal variability of rainfall in the Gandaki River Basin of Nepal Himalaya, Climate, 3, 210-226, 2015.

Pacyna, J. M., Travnikov, O., De Simone, F., Hedgecock, I. M., Sundseth, K., Pacyna, E. G., Steenhuisen, F., Pirrone, N., Munthe, J., and Kindbom, K.: Current and future levels of mercury atmospheric pollution on a global scale, Atmos. Chem. Phys., 16, 12495-12511, https://doi.org/10.5194/acp-16-124952016, 2016.

Pokhrel, B., Gong, P., Wang, X., Gao, S., Wang, C., and Yao, T.: Sources and environmental processes of polycyclic aromatic hydrocarbons and mercury along a southern slope of the Central Himalayas, Nepal, Environ. Sci. Pollut. R., 23, 13843-13852, 2016

Polissar, A., Hopke, P., Paatero, P., Kaufmann, Y., Hall, D., Bodhaine, B., Dutton, E., and Harris, J.: The aerosol at Barrow, Alaska: long-term trends and source locations, Atmos. Environ., 33, 2441-2458, 1999.

Prestbo, E. M. and Gay, D. A.: Wet deposition of mercury in the US and Canada, 1996-2005: Results and analysis of the NADP mercury deposition network (MDN), Atmos. Environ., 43, 42234233, 2009.

Qiu, J.: China: the third pole, Nature News, 454, 393-396, 2008.

Quan, J., Gao, Y., Zhang, Q., Tie, X., Cao, J., Han, S., Meng, J., Chen, P., and Zhao, D.: Evolution of planetary boundary layer under different weather conditions, and its impact on aerosol concentrations, Particuology, 11, 34-40, 2013.
Rahman, M. M., Mahamud, S., and Thurston, G. D.: Recent spatial gradients and time trends in Dhaka, Bangladesh air pollution and their human health implications, J. Air Waste Ma., 1-24, https://doi.org/10.1080/10962247.2018.1548388, 2018.

Rana, M. M., Sulaiman, N., Sivertsen, B., Khan, M. F., and Nasreen, S.: Trends in atmospheric particulate matter in Dhaka, Bangladesh, and the vicinity, Environ. Sci. Pollut. R., 23, 1739317403, 2016.

Rhode, D., Madsen, D. B., Brantingham, P. J., and Dargye, T.: Yaks, yak dung, and prehistoric human habitation of the Tibetan Plateau, Developments in Quaternary Sciences, 9, 205224, 2007.

Rupakheti, D., Adhikary, B., Praveen, P. S., Rupakheti, M., Kang, S., Mahata, K. S., Naja, M., Zhang, Q., Panday, A. K., and Lawrence, M. G.: Pre-monsoon air quality over Lumbini, a world heritage site along the Himalayan foothills, Atmos. Chem. Phys., 17, 11041-11063, https://doi.org/10.5194/acp-17-110412017, 2017.

Rutter, A. P., Schauer, J. J., Lough, G. C., Snyder, D. C., Kolb, C. J., Von Klooster, S., Rudolf, T., Manolopoulos, H., and Olson, M L.: A comparison of speciated atmospheric mercury at an urban center and an upwind rural location, J. Environ. Monitor., 10, 102-108, 2008.

Seigneur, C., Vijayaraghavan, K., and Lohman, K.: Atmospheric mercury chemistry: Sensitivity of global model simulations to chemical reactions, J. Geophys. Res.-Atmos., 111, D22306, 2006.

Selin, N. E.: Global biogeochemical cycling of mercury: a review, Annu. Rev. Env. Resour., 34, 43-63, 2009.

Sharma, D. C.: Concern over mercury pollution in India, Lancet, 362, 1050, https://doi.org/10.1016/S0140-6736(03)14456-X, 2003.

Simone, F. D., Gencarelli, C. N., Hedgecock, I. M., and Pirrone, N.: A modeling comparison of mercury deposition from current anthropogenic mercury emission inventories, Environ. Sci. Technol., 50, 5154-5162, 2016.

Slemr, F., Angot, H., Dommergue, A., Magand, O., Barret, M., Weigelt, A., Ebinghaus, R., Brunke, E.-G., Pfaffhuber, K. A., Edwards, G., Howard, D., Powell, J., Keywood, M., and Wang, F. Comparison of mercury concentrations measured at several sites in the Southern Hemisphere, Atmos. Chem. Phys., 15, 31253133, https://doi.org/10.5194/acp-15-3125-2015, 2015.

Slemr, F., Weigelt, A., Ebinghaus, R., Kock, H. H., Bödewadt, J., Brenninkmeijer, C. A. M., Rauthe-Schöch, A., Weber, S., Hermann, M., Becker, J., Zahn, A., and Martinsson, B.: Atmospheric mercury measurements onboard the CARIBIC passenger aircraft, Atmos. Meas. Tech., 9, 2291-2302, https://doi.org/10.5194/amt-9-2291-2016, 2016.

Song, Y., Zhu, T., Cai, X., Lin, W., and Kang, L.: Glacier winds in the Rongbuk Valley, north of Mount Everest: 1. Meteorological modeling with remote sensing data, J. Geophys. Res.-Atmos., 112, D11101, https://doi.org/10.1029/2006JD007867, 2007.

Sprovieri, F., Pirrone, N., Bencardino, M., D’Amore, F., Carbone, F., Cinnirella, S., Mannarino, V., Landis, M., Ebinghaus, R., Weigelt, A., Brunke, E.-G., Labuschagne, C., Martin, L., Munthe, J., Wängberg, I., Artaxo, P., Morais, F., Barbosa, H. D. M. J., Brito, J., Cairns, W., Barbante, C., Diéguez, M. D. C., Garcia, P. E., Dommergue, A., Angot, H., Magand, O., Skov, H., Horvat, M., Kotnik, J., Read, K. A., Neves, L. M., 
Gawlik, B. M., Sena, F., Mashyanov, N., Obolkin, V., Wip, D., Feng, X. B., Zhang, H., Fu, X., Ramachandran, R., Cossa, D., Knoery, J., Marusczak, N., Nerentorp, M., and Norstrom, C.: Atmospheric mercury concentrations observed at groundbased monitoring sites globally distributed in the framework of the GMOS network, Atmos. Chem. Phys., 16, 11915-11935, https://doi.org/10.5194/acp-16-11915-2016, 2016.

Stein, A., Draxler, R. R., Rolph, G. D., Stunder, B. J., Cohen, M., and Ngan, F.: NOAA's HYSPLIT atmospheric transport and dispersion modeling system, B. Am. Meteorol. Soc., 96, 20592077, 2015.

Streets, D. G., Devane, M. K., Lu, Z., Bond, T. C., Sunderland, E. M., and Jacob, D. J.: All-time releases of mercury to the atmosphere from human activities, Environ. Sci. Technol., 45, 1048510491, 2011.

Swartzendruber, P., Jaffe, D., and Finley, B.: Improved fluorescence peak integration in the Tekran 2537 for applications with suboptimal sample loadings, Atmos. Environ., 43, 3648-3651, 2009.

Tang, Y., Wang, S., Wu, Q., Liu, K., Wang, L., Li, S., Gao, W., Zhang, L., Zheng, H., Li, Z., and Hao, J.: Recent decrease trend of atmospheric mercury concentrations in East China: the influence of anthropogenic emissions, Atmos. Chem. Phys., 18, 8279-8291, https://doi.org/10.5194/acp-18-8279-2018, 2018.

Tie, X., Madronich, S., Li, G., Ying, Z., Zhang, R., Garcia, A. R., Lee-Taylor, J., and Liu, Y.: Characterizations of chemical oxidants in Mexico City: A regional chemical dynamical model (WRF-Chem) study, Atmos. Environ., 41, 1989-2008, 2007.

Tong, Y., Yin, X., Lin, H., Wang, H., Deng, C., Chen, L., Li, J., Zhang, W., Schauer, J. J., and Kang, S.: Recent Decline of Atmospheric Mercury Recorded by Androsace tapete on the Tibetan Plateau, Environ. Sci. Technol., 50, 13224-13231, 2016.

Travnikov, O., Angot, H., Artaxo, P., Bencardino, M., Bieser, J., D'Amore, F., Dastoor, A., De Simone, F., Diéguez, M. D. C., Dommergue, A., Ebinghaus, R., Feng, X. B., Gencarelli, C. N., Hedgecock, I. M., Magand, O., Martin, L., Matthias, V., Mashyanov, N., Pirrone, N., Ramachandran, R., Read, K. A., Ryjkov, A., Selin, N. E., Sena, F., Song, S., Sprovieri, F., Wip, D., Wängberg, I., and Yang, X.: Multi-model study of mercury dispersion in the atmosphere: atmospheric processes and model evaluation, Atmos. Chem. Phys., 17, 5271-5295, https://doi.org/10.5194/acp-17-5271-2017, 2017.

Venter, A. D., Beukes, J. P., van Zyl, P. G., Brunke, E.-G., Labuschagne, C., Slemr, F., Ebinghaus, R., and Kock, H.: Statistical exploration of gaseous elemental mercury (GEM) measured at Cape Point from 2007 to 2011, Atmos. Chem. Phys., 15, 10271-10280, https://doi.org/10.5194/acp-15-10271-2015, 2015.

Wang, B., Wu, R., and Lau, K.: Interannual variability of the Asian summer monsoon: Contrasts between the Indian and the western North Pacific-East Asian monsoons, J. Climate, 14, 4073-4090, 2001.

Wang, C., Wang, X., Gong, P., and Yao, T.: Long-term trends of atmospheric organochlorine pollutants and polycyclic aromatic hydrocarbons over the southeastern Tibetan Plateau, Sci. Total Environ., 624, 241-249, 2018.

Wang, X., Gong, P., Sheng, J., Joswiak, D. R., and Yao, T.: Longrange atmospheric transport of particulate Polycyclic Aromatic Hydrocarbons and the incursion of aerosols to the southeast Tibetan Plateau, Atmos. Environ., 115, 124-131, 2015.
Ward Jr., J. H.: Hierarchical grouping to optimize an objective function, J. Am. Stat. Assoc., 58, 236-244, 1963.

Weiss-Penzias, P., Gustin, M. S., and Lyman, S. N.: Observations of speciated atmospheric mercury at three sites in Nevada: Evidence for a free tropospheric source of reactive gaseous mercury, J. Geophys. Res.-Atmos., 114, D14302, https://doi.org/10.1029/2008JD011607, 2009.

World Bank: China - Capacity Strengthening for Implementation of Minamata Convention on Mercury Project, Washington, DC, World Bank Group, 2016.

Wu, Q., Wang, S., Li, G., Liang, S., Lin, C.-J., Wang, Y., Cai, S., Liu, K., and Hao, J.: Temporal trend and spatial distribution of speciated atmospheric mercury emissions in China during 19782014, Environ. Sci. Technol., 50, 13428-13435, 2016.

Wu, Q., Li, G., Wang, S., Liu, K., and Hao, J.: Mitigation options of atmospheric $\mathrm{Hg}$ emissions in China, Environ. Sci. Technol., 52, 12368-12375, 2018.

Xiao, Q., Saikawa, E., Yokelson, R. J., Chen, P., Li, C., and Kang, S.: Indoor air pollution from burning yak dung as a household fuel in Tibet, Atmos. Environ., 102, 406-412, https://doi.org/10.1016/j.atmosenv.2014.11.060, 2015.

Xu, B., Cao, J., Hansen, J., Yao, T., Joswia, D. R., Wang, N., Wu, G., Wang, M., Zhao, H., and Yang, W.: Black soot and the survival of Tibetan glaciers, P. Natl. Acad. Sci., 106, 22114-22118, 2009.

Yang, J., Kang, S., Ji, Z., and Chen, D.: Modeling the origin of anthropogenic black carbon and its climatic effect over the Tibetan Plateau and surrounding regions, J. Geophys. Res.-Atmos., 123, 671-692, 2018.

Yao, T., Thompson, L. G., Mosbrugger, V., Zhang, F., Ma, Y., Luo, T., Xu, B., Yang, X., Joswiak, D. R., and Wang, W.: Third pole environment (TPE), Environmental Development, 3, 52-64, 2012.

Yin, X., Kang, S., de Foy, B., Ma, Y., Tong, Y., Zhang, W., Wang, X., Zhang, G., and Zhang, Q.: Multi-year monitoring of atmospheric total gaseous mercury at a remote high-altitude site (Nam Co, $4730 \mathrm{~m}$ a.s.l.) in the inland Tibetan Plateau region, Atmos. Chem. Phys., 18, 10557-10574, https://doi.org/10.5194/acp-18-105572018, 2018.

Zhang, H., Fu, X. W., Lin, C.-J., Wang, X., and Feng, X. B.: Observation and analysis of speciated atmospheric mercury in ShangriLa, Tibetan Plateau, China, Atmos. Chem. Phys., 15, 653-665, https://doi.org/10.5194/acp-15-653-2015, 2015.

Zhang, H., Fu, X., Lin, C.-J., Shang, L., Zhang, Y., Feng, X., and Lin, C.: Monsoon-facilitated characteristics and transport of atmospheric mercury at a high-altitude background site in southwestern China, Atmos. Chem. Phys., 16, 13131-13148, https://doi.org/10.5194/acp-16-13131-2016, 2016.

Zhang, L., Wang, S. X., Wang, L., and Hao, J. M.: Atmospheric mercury concentration and chemical speciation at a rural site in Beijing, China: implications of mercury emission sources, Atmos. Chem. Phys., 13, 10505-10516, https://doi.org/10.5194/acp-13-10505-2013, 2013.

Zhang, R., Wang, H., Qian, Y., Rasch, P. J., Easter, R. C., Ma, P.L., Singh, B., Huang, J., and Fu, Q.: Quantifying sources, transport, deposition, and radiative forcing of black carbon over the Himalayas and Tibetan Plateau, Atmos. Chem. Phys., 15, 62056223, https://doi.org/10.5194/acp-15-6205-2015, 2015. 
Zhang, Y., Jacob, D. J., Horowitz, H. M., Chen, L., Amos, H. M., Krabbenhoft, D. P., Slemr, F., Louis, V. L. S., and Sunderland, E. M.: Observed decrease in atmospheric mercury explained by global decline in anthropogenic emissions, P. Natl. Acad. Sci., 113, 526-531, 2016.
Zhu, T., Lin, W., Song, Y., Cai, X., Zou, H., Kang, L., Zhou, L., and Akimoto, H.: Downward transport of ozonerich air near Mt. Everest, Geophys. Res. Lett., 33, L23809, https://doi.org/10.1029/2006GL027726, 2006. 